\title{
Emerging Market Heterogeneity:
} Insights from Cluster and Taxonomy Analysis 


\section{WP/15/155}

\section{IMF Working Paper}

\section{Emerging Market Heterogeneity: Insights from Cluster and Taxonomy Analysis}

by Zhongxia Zhang and Yuan Gao

IMF Working Papers describe research in progress by the author(s) and are published to elicit comments and to encourage debate. The views expressed in IMF Working Papers are those of the author(s) and do not necessarily represent the views of the IMF, its Executive Board, or IMF management.
I $\mathrm{N}$
R N A T I O N A L
$M O N E T A R Y$
F U N D 


\title{
IMF Working Paper
}

Strategy, Policy, and Review Department

\section{Emerging Market Heterogeneity: Insights from Cluster and Taxonomy Analysis \\ Prepared by Zhongxia Zhang and Yuan Gao \\ Authorized for distribution by Luis Cubeddu}

July 2015

\begin{abstract}
IMF Working Papers describe research in progress by the author(s) and are published to elicit comments and to encourage debate. The views expressed in IMF Working Papers are those of the author(s) and do not necessarily represent the views of the IMF, its Executive Board, or IMF management.
\end{abstract}

\begin{abstract}
This paper studies growth patterns in Emerging Market Economies (EMs) from the perspective on clusters and taxonomies. First, it documents developments over the past five decades in EMs and uses a cluster analysis to better understand convergence and the investment-growth nexus. Second, it looks at the performance of EMs since 2000 and develops a taxonomy to classify countries according to their factor endowments as well as their real and financial external linkages. The taxonomy offers insights on growth dynamics pre and post the global financial crisis. Results highlight the high degree of heterogeneity in EMs and the need for more granular and targeted near and long-term policy advice.
\end{abstract}

JEL Classification Numbers: E32, F43, O11, O47

Keywords: emerging markets, growth, heterogeneity, cluster analysis, taxonomy

Author's E-Mail Address: ZZhang2@imf.org, YGao@imf.org 


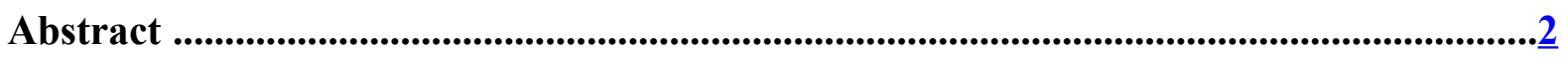

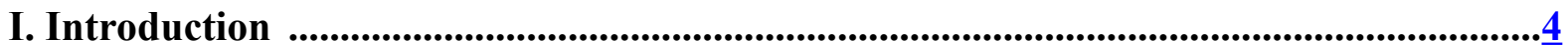

II. Long-term Development and Cluster Analysis ...........................................................5

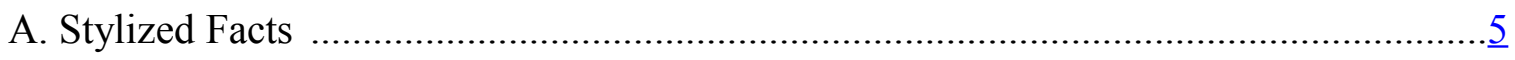

B. Cluster Methodology and Results ....................................................................... $\frac{7}{2}$

C. Refining Economic Convergence Classification ...............................................

D. Understanding Investmnet-Growth-Unemployment Nexus ..................................16

III. Recent Performance and Taxonomy of Emerging Markets ......................................17

A. Taxonomy Methodology and Results .............................................................

B. Explaining the Degree of Economic Recovery ….............................................

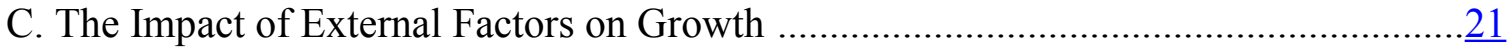

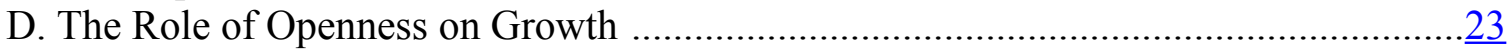

E. Trade Linkages and Spillover Effects ...........................................................

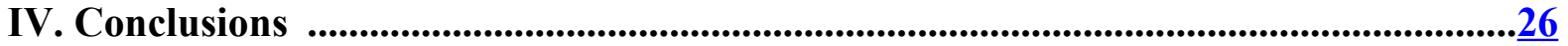

Figures

1. Output as Share of World GDP (PPP-adjusted) .......................................................

2. GDP per Capita (PPP-adjusted) Relative to the U.S. ..................................................

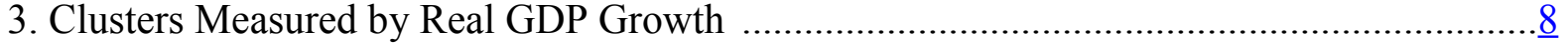

4. Clusters Measured by GDP Growth and Investment ..................................................10

5. Clusters Measured by GDP Growth and Consumption .............................................10

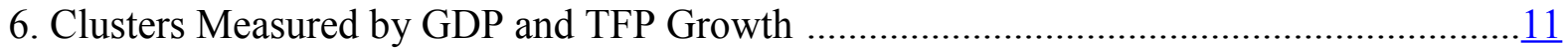

7. Venn Diagrams for Clusters Comparison ................................................................12

8. Investment Boom-Bust Cycle by External Financing Type .........................................13

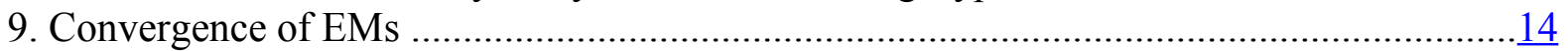

10. Unemployment Rate vs. Real Investment Share ......................................................16

11. Taxonomy Output of Domestic Indicators ............................................................ 18

12. Taxonomy Output and Distribution of External Indicators ......................................19

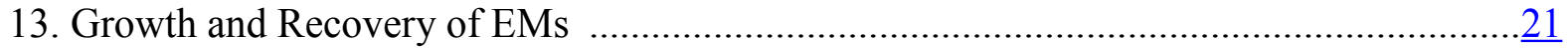

14. The Impacts of External Factors on Growths ........................................................22

15. The Impacts on Growth from Commodity Boom and Global Imbalances Adjusted by

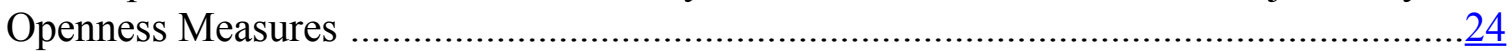

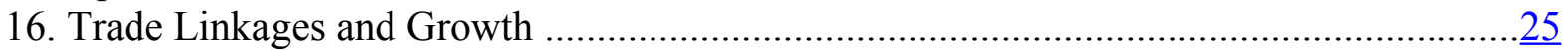

Table

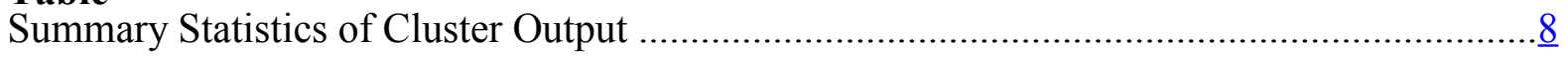

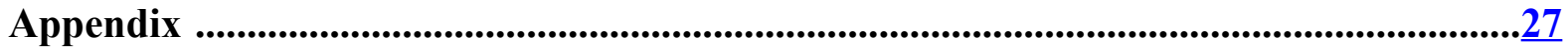

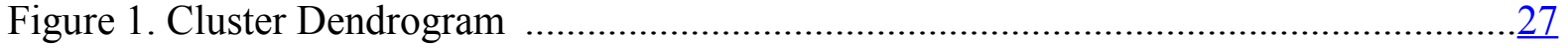

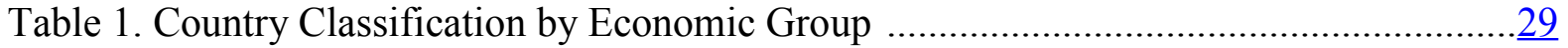

Table 2. Country Coverage in Cluster Analysis .............................................................. $\underline{30}$

Table 3. Country Coverage in Taxonomy Analysis ...................................................... $\frac{30}{31}$

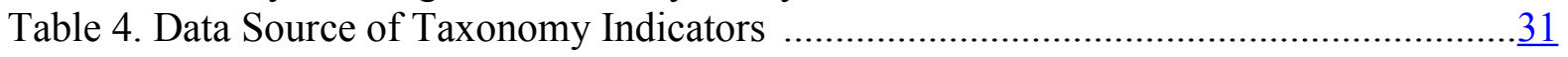

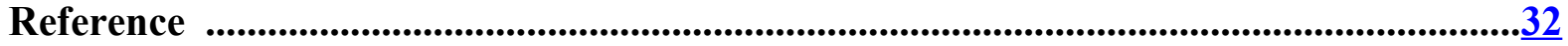




\section{INTRODUCTION ${ }^{1}$}

Emerging Market Economies (EMs) ${ }^{2}$ have played an increasingly important role in the world stage, attracting attention from policymakers, researchers, and investors. EMs' output share in the global economy has doubled in the last five decades, and today represents over 50 percent of the total global output at purchasing power parity (PPP). Moreover, EMs currently account for over half of the global population and their importance is forecasted to increase further if their growth rates remain at a faster level than Advanced Market Economies (AMs).

Although EMs as a group have made great achievements over the past five decades, progress is uneven within the group. Since 1960, some EMs have seen their income levels converging to that in the United States, others have witnessed relatively stagnant income levels. The Global Financial Crisis (GFC) also had differential economic impacts across EMs. This study attempts to document what makes emerging markets different. Few papers had so far looked at the heterogeneity among EMs. Traditionally, EMs have been classified in terms of geographic region or income level (World Bank 2013) as well as in terms of development (e.g., Tezanos Vázqueza et al. 2013). The IMF's 2014 April World Economic Outlook (WEO) documented the heterogeneity across emerging market economies by ranking 16 large EMs according to six dimensions of economic and structural characteristics.

This paper takes a further step forward to examine the heterogeneity of the EMs group from different dimensions and contributes to the literature of economic clusters and taxonomy. First, it proposes new clusters based on EMs' long-term development trend on growth and its driving factors over the past five decades. The growth clusters identified in our study have more explanatory power in understanding convergence than the traditional geographic classification. We found an interesting relationship between long-term growth and investment clusters: investment clusters are highly correlated with growth clusters. In addition, Total Factor Productivity (TFP) growth and real GDP growth clusters are strongly correlated. On the investment-growth-unemployment nexus, on average countries in the high investment-growth group show low unemployment rates, while countries in the low investment-growth group display high unemployment rates. Second, this paper provides a taxonomy based on EMs' revealed factor endowments from the domestic angle and linkages

\footnotetext{
${ }^{1}$ This paper is part of a background paper series for IMF Staff Discussion Note 14/6 (Washington) entitled "Emerging Markets in Transition: Growth Prospects and Challenges". The authors thank Luis Cubeddu for his guidance, Tamim Bayoumi, Rupa Duttagupta, Chris Papageorgiou, Ceyda Oner, Evridiki Tsounta, Ran Bi, Ghada Fayad, and participants in the IMF Strategy, Policy, and Review Department seminar for their valuable comments, Gillian Adu for publication assistance. All errors are our own.

${ }^{2}$ Emerging Market is a new terminology of country group. In this study, we have included nine Newly Industrialized Economies (Czech Rep., Estonia, Hong Kong SAR, Israel, Korea, Singapore, Slovak Rep., Slovenia, and Taiwan POC) in EMs group and classified countries that are eligible for the IMF PRGT (Poverty Reduction and Growth Trust) lending program and Zimbabwe as low-income countries (see Appendix Table 1).
} 
from the external angle since 2000. Results have shown that the degree of economic recovery can be explained by our domestic angle taxonomy to the extent whether an economy is mainly consumption-led or investment-led. The external angle taxonomy interprets growth dynamics pre and post the GFC: the degree of economic slowdown, growth surprise, and business cycle synchronization are all positively correlated with the degree of our external factor index. We looked at terms of trade changes adjusted by commodity export and trade openness measures, and cumulative current account deficits adjusted by financial openness. Results suggest that increased openness has an amplifying effect in transmitting terms of trade shocks and external adjustment pressure on growth. In addition, we illustrated the spillover effects from trade linkages. One country's growth can benefit significantly from, or dragged by its trading partners. To the best of our knowledge, our paper is the first work that attempts to classify the emerging markets in a systematic approach.

The remainder of the paper is structured as follows. Section II documents EMs' developments over the past five decades, including distinct growth paths and convergence to high-income levels. Based on the long-term trend, a number of country clusters are identified to better understand convergence and the investment-growth-unemployment nexus. Section III documents developments in EMs since 2000, distinguishing performance before and after the GFC. In order to examine the heterogeneity in growth dynamics among EMs, a new taxonomy that goes beyond geographical and income classification is proposed, and groups EMs according to their factor endowments as well as external, real, and financial linkages. The usefulness of our taxonomy is illustrated in explaining the degree of economic recovery since the GFC, differentiating the impact of external factors on growth, how commodity price booms and global imbalances affect growth through the role of openness, and spillover effects from trade linkages. Section IV concludes.

\section{LONG-TERM DEVELOPMENT AND CLUSTER ANALYSIS}

\section{A. Stylized Facts}

Over the past five decades, EMs grew at a very rapid pace and their contribution to global output has increased substantially. Based on the Penn World Table (PWT) and WEO data, EMs' share of global PPP-adjusted GDP increased from 27 percent in 1960 to around 53 percent by 2013, and it exceeded the share of AMs in 2009, reflecting consistently higher average growth rates. Five countries account for about half of EMs' total outputs (Figure 1). As of 2013, the size of PPP-adjusted GDP for China, India, Russia, Brazil, and Mexico were comparable to that of the United States, Japan, Germany, France, and the United Kingdom.

However, there are large disparities in growth performance among EMs. Using PWT data we investigate whether EMs were able to move from one income level to the next over the 
Figure 1. Output as Share of World GDP (PPP-adjusted) ${ }^{12 /}$

(Decomposition by Economic Group and Country)

1960

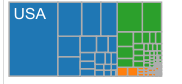

AMs $\square$ EMs $\square$ LICS

1970

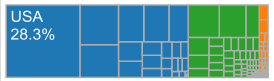

1980

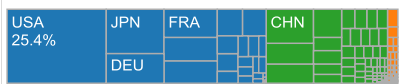

1990

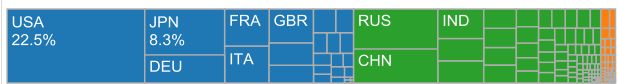

2000

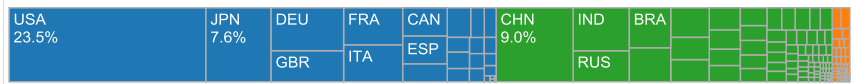

2010
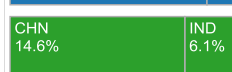

\begin{tabular}{l|l} 
USA \\
II & $19.0 \%$
\end{tabular}
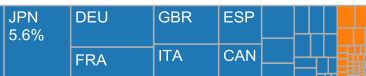

2013

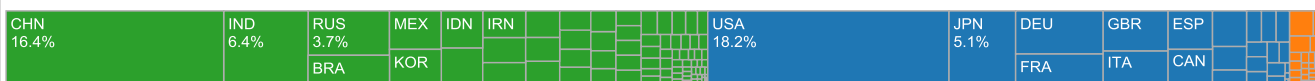

Sources: Penn World Table 8.0, WEO and IMF staff calculations.

$1 /$ The length of the horizontal bar represents global GDP outputs (PPP-adjusted, in Mil of 2005US\$). Each rectangle represents the

country's PPP-adjusted GDP share to the world. Country coverage of each group is listed in Appendix Table 1.

2/ The shares of AMs, EMs and LICs in 2013 are 44, 52.7, and 3.3 percent, respectively.

Figure 2. GDP per Capita (PPP-adjusted) Relative to the U.S. ${ }^{12 /}$

(Log of percent, 1960 and 2013)

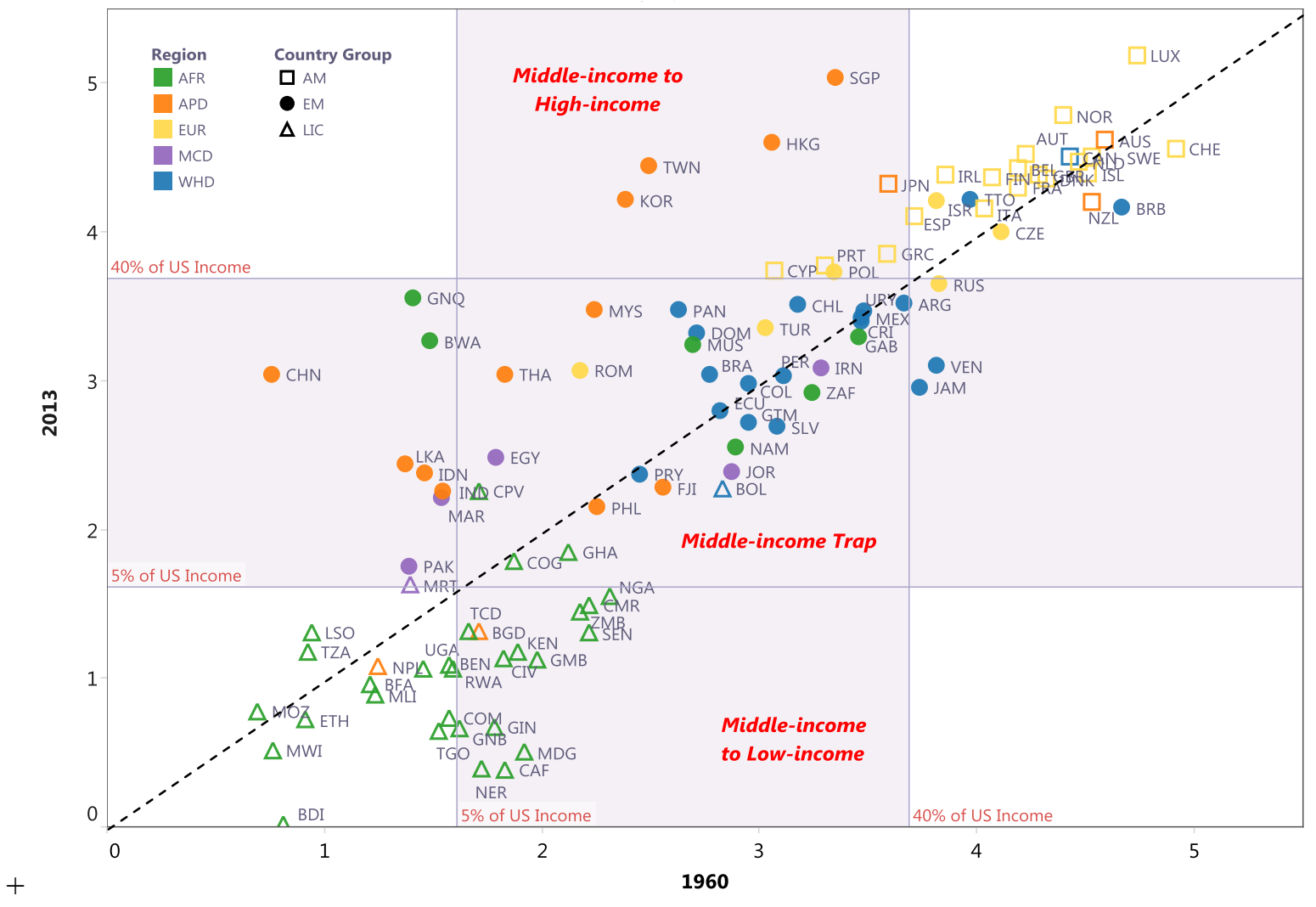

Sources: Maddison Database, Penn World Table 7.1, WEO and IMF staff calculations.

1/ AFR=Africa, $A P D=A s i a$ and Pacific, EUR=Europe, $M C D=$ Middle East and Central Asia, WHD=Western Hemisphere.

2/ Czech Republic and Russia's historical data were extrapolated using the GDP per capita growth rate of Czechoslovakia and the former Soviet Union from Maddison database. 
period of 1960-2013. ${ }^{3}$ Our analysis, which is largely consistent with the latest World Bank classification of income groups, ${ }^{4}$ suggests that only a few EMs were able to advance to highincome status, while many have been stuck in a middle income trap since the 1960s.

Figure 2 indicates that EMs - irrespective of geographical location - did not behave in a consistent manner in terms of their convergence dynamics. For example, 64 percent of the EMs, originating from all regions, are stuck in the so called "middle-income trap", while a few economies in Asia and Europe have successfully transformed into high-income countries, including the "the Four Asian Tigers".

\section{B. Cluster Methodology and Results}

The question that arises is what explains this divergent performance? To answer this question we have applied cluster analysis to identify the patterns of economic performance among the EM universe. A total of 25 major EMs are selected for our cluster analysis based on their economic size, growth rate and data availability during 1980-2013. ${ }^{5}$ Using WEO 2014 data we identify clusters for our sample using Ward's linkage method. ${ }^{6}$ Four clusters are chosen based on the sensitivity test.

Cluster analysis has a long history of applications and the simplest way is to use one variable in the analysis. We start with the one-variable approach. The variable we choose is real GDP growth rate, which is the most important factor for economic catch-up. We set five years as an interval and calculate each economy's simple average of growth rates on these seven intervals over the period of 1980 to 2013 . $^{7}$ Four clusters have been identified using Ward's linkage method based on the period average growth data: "Low Growth Group", "Increasing Growth Group", "Declining Growth Group", and "High Growth Group" (Figure 3). The Low

\footnotetext{
${ }^{3}$ Following Agénor, Canuto, and Jelenic (2012), we set the lower and upper thresholds of middle income status at 5 and 40 percent of the corresponding U.S. GDP per capita level (PPP-adjusted) in the same year.

${ }^{4}$ The most recent World Bank classification of income groups (for $2015 \mathrm{FY}$ ) is as follows: low-income economics are defined as countries with a GNI per capita of $\$ 1045$ or less; middle-income economics are countries with a GNI per capita between \$1046 and \$12745; high-income economies are countries with a GNI per capita of $\$ 12746$ or above. There is an overlap of 87.2 percent between our and World Bank's classification based on a sample of 164 countries in 2013. http://data.worldbank.org/about/country-classifications

${ }^{5}$ See country coverage in Appendix Table 2. We focus on major EMs because the motivation of this section is to study long-term growth patterns of large EMs, and the 25 economies in this sample exhibit considerable heterogeneity in growth. Running the same type of exercise with a larger sample as in section III yields broadly consistent results.

${ }^{6}$ Appendix on Cluster Methodology describes the details.

${ }^{7}$ We conducted sensitivity analysis using annual data, instead of 5-year simple average data, to run the cluster analysis. The results are largely consistent. Moreover, using period average data can minimize the effect of missing data and data spike in a particular year.
} 
Figure 3. Clusters Measured by Real GDP Growth

(In percent, real terms)
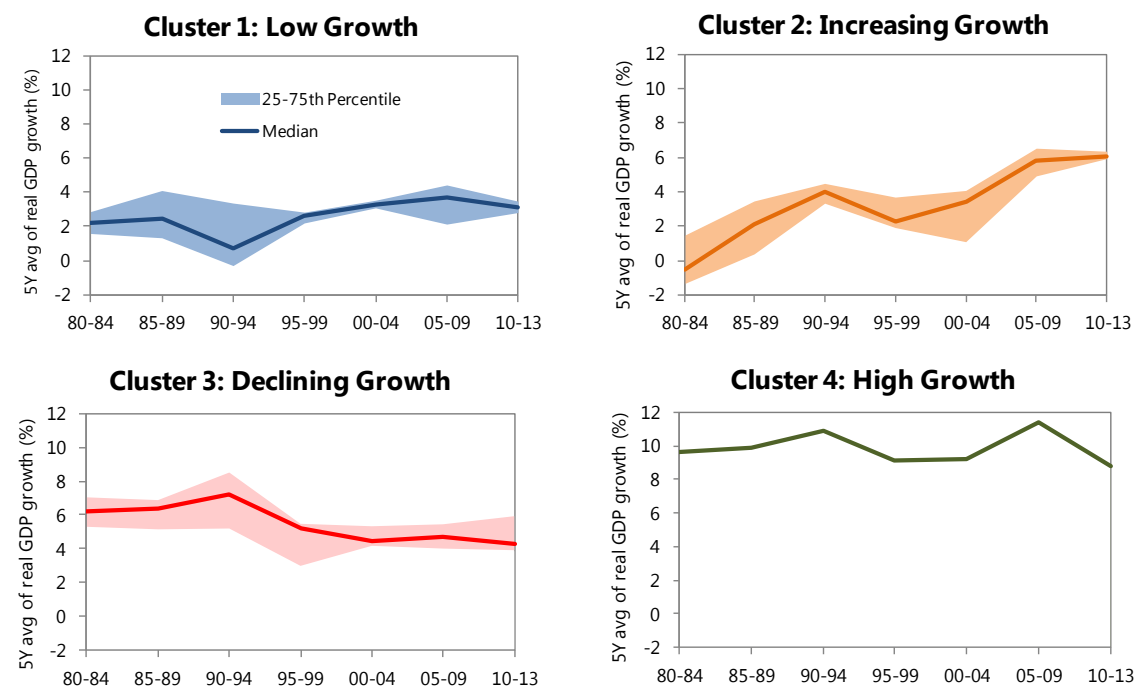

Sources: WEO and IMF staff calculations.

Cluster 1: Brazil, Colombia, Hungary, Mexico, Poland, and South Africa;

Cluster 2: Argentina, Peru, Philippines, Saudi Arabia, Turkey, Uruguay, and Venezuela;

Cluster 3: Chile, Egypt, Hong Kong SAR, India, Indonesia, Israel, Korea, Malaysia, Pakistan, Singapore, and Thailand;

Cluster 4: China.

Table 1. Summary Statistics of Cluster Output

\begin{tabular}{|c|c|c|c|c|c|c|c|}
\hline & & Variable & Mean & Std. dev & $\min$ & $\max$ & \# of Obs \\
\hline \multirow{4}{*}{$\begin{array}{l}\text { Growth } \\
\text { Clusters }\end{array}$} & Cluster 1: low growth & \multirow{4}{*}{ real GDP growth } & 2.49 & 1.91 & -3.22 & 5.91 & 42 \\
\hline & Cluster 2: increasing growth & & 3.17 & 2.49 & -2.24 & 6.83 & 49 \\
\hline & Cluster 3: declining growth & & 5.35 & 1.88 & 0.73 & 10.08 & 77 \\
\hline & Cluster 4: high growth & & 9.84 & 0.96 & 8.77 & 11.40 & 7 \\
\hline \multirow{8}{*}{$\begin{array}{l}\text { Growth and } \\
\text { Investment } \\
\text { Clusters }\end{array}$} & Cluster 1: low investment & \multirow{4}{*}{ real GDP growth } & 3.29 & 2.15 & -3.22 & 7.28 & 98 \\
\hline & Cluster 2: increasing investment & & 4.06 & 2.80 & -1.64 & 8.14 & 14 \\
\hline & Cluster 3: declining investment & & 5.66 & 2.28 & 1.54 & 9.14 & 21 \\
\hline & Cluster 4: high investment & & 8.25 & 2.90 & 3.37 & 13.05 & 14 \\
\hline & Cluster 1: low investment & \multirow{4}{*}{ investment/GDP } & 18.30 & 3.65 & 10.90 & 28.67 & 98 \\
\hline & Cluster 2: increasing investment & & 26.84 & 4.77 & 20.62 & 33.68 & 14 \\
\hline & Cluster 3: declining investment & & 27.16 & 4.67 & 20.47 & 40.22 & 21 \\
\hline & Cluster 4: high investment & & 32.61 & 5.56 & 25.13 & 44.64 & 14 \\
\hline \multirow{8}{*}{$\begin{array}{l}\text { Growth and } \\
\text { Consumption } \\
\text { Clusters }\end{array}$} & Cluster 1: low consumption & \multirow{4}{*}{ real GDP growth } & 5.95 & 3.16 & 0.73 & 13.05 & 35 \\
\hline & Cluster 2: increasing consumption & & 2.40 & 2.33 & -3.22 & 6.23 & 42 \\
\hline & Cluster 3: declining consumption & & 5.72 & 1.93 & 1.61 & 10.08 & 21 \\
\hline & Cluster 4: high consumption & & 3.92 & 1.57 & -0.18 & 6.83 & 42 \\
\hline & Cluster 1: low consumption & \multirow{4}{*}{ consumption/GDP } & 60.51 & 8.20 & 45.07 & 77.52 & 35 \\
\hline & Cluster 2: increasing consumption & & 79.22 & 5.16 & 66.66 & 88.88 & 42 \\
\hline & Cluster 3: declining consumption & & 75.52 & 6.23 & 65.77 & 88.94 & 21 \\
\hline & Cluster 4: high consumption & & 84.35 & 7.97 & 61.28 & 107.43 & 42 \\
\hline \multirow{8}{*}{$\begin{array}{l}\text { Growth and } \\
\text { TFP Growth } \\
\text { Clusters }\end{array}$} & Cluster 1: low and sluggish TFP growth & \multirow{4}{*}{ real GDP growth } & 2.48 & 1.95 & -3.22 & 6.23 & 42 \\
\hline & Cluster 2: low and volatile TFP growth & & 2.88 & 2.77 & -2.24 & 6.83 & 35 \\
\hline & Cluster 3: moderate TFP growth & & 4.97 & 1.97 & 0.73 & 10.08 & 63 \\
\hline & Cluster 4: high TFP growth & & 6.72 & 2.35 & 3.16 & 11.40 & 28 \\
\hline & Cluster 1: low and sluggish TFP growth & \multirow{4}{*}{ TFP growth } & -0.22 & 1.92 & -5.15 & 4.41 & 42 \\
\hline & Cluster 2: low and volatile TFP growth & & -0.32 & 3.14 & -9.68 & 6.21 & 35 \\
\hline & Cluster 3: moderate TFP growth & & 0.29 & 1.48 & -3.62 & 3.32 & 63 \\
\hline & Cluster 4: high TFP growth & & 1.57 & 1.80 & -1.50 & 5.17 & 28 \\
\hline
\end{tabular}

Note: the discrepancy of maximum values between different cluster outputs is due to the missing values in early years. 
Growth Group is comprised of six countries, and they have a relatively low growth rate, around 2.5 percent on an annual basis (Table 1). The Increasing Growth Group, which includes seven countries, began with a slow growth pace. It has seen growth acceleration in the later stage, although there is a large amount of variation in growth rates. In contrast, the Declining Growth Group, which includes eleven economies, began with a fast growth pace, then its growth declined gradually and stabilized around 4 percent on an annual basis. The moderate shift in trend growth is accompanied by smaller dispersion in growth rates, compared to the Increasing Growth Group. China is the only country in the High Growth Group because China's growth rate is exceptionally high compared to its peers through the sample period. If we force the cluster number to be two, cluster 1 and 2 will be combined into one group, and cluster 3 and 4 will be merged into another group.

The above results show how each group performs measured by output growth. However, it is not clear what the driving factors are behind the fast or slow GDP growth, and whether countries that belong to the same cluster share similarities in their growth components. Therefore, in the second stage, we employ two measure variables in the cluster analysis. In addition to the real GDP growth rate, we add the investment share in percent of GDP, the consumption share in percent of GDP, and Total Factor Productivity (TFP) growth rate separately. This enables us to understand the interaction between the total output and its main contributing factors. ${ }^{8}$

Based on the magnitude and co-movement of real GDP growth and real investment share in GDP, four clusters have been identified: "Low Investment Group", "Increasing Investment Group", "High Investment Group", and "Declining Investment Group" (Figure 4). The Low Investment Group's investment share in GDP is the lowest-less than 20 percent of total output, and as a result growth has underperformed compared to other groups, only at an annual rate of 3.3 percent (Table 1). Investment share in the Increasing Investment Group has surpassed 30 percent after 2000 and growth accelerated at the same time. The Declining Investment Group's investment share has been in a boom-bust episode due to the 1997 Asian Crisis, and the share has dropped gradually since, accompanied by a growth slowdown after 2000. In the High Investment Group, investment made up more than 30 percent of total output, and its growth rate is also the highest among all groups.

Similarly, an analysis of real GDP growth and real consumption share in GDP has identified four clusters: "Low Consumption Group", "Increasing Consumption Group", "Declining Consumption Group", and "High Consumption Group" (Figure 5). The Low Consumption Group's consumption share to GDP is the lowest - around 60 percent, while its growth rate is

\footnotetext{
${ }^{8}$ An alternative approach is to use one variable to obtain clusters. In this way, investment share, consumption share, or TFP growth will be the only input variable used in the cluster analysis to classify countries. We find similar but weaker results. In some cases, the optimal number of clusters based on the dendrogram is no longer four, and therefore results are less comparable.
} 
Figure 4. Clusters Measured by GDP Growth and Investment

(In percent and in percent of GDP, real terms)
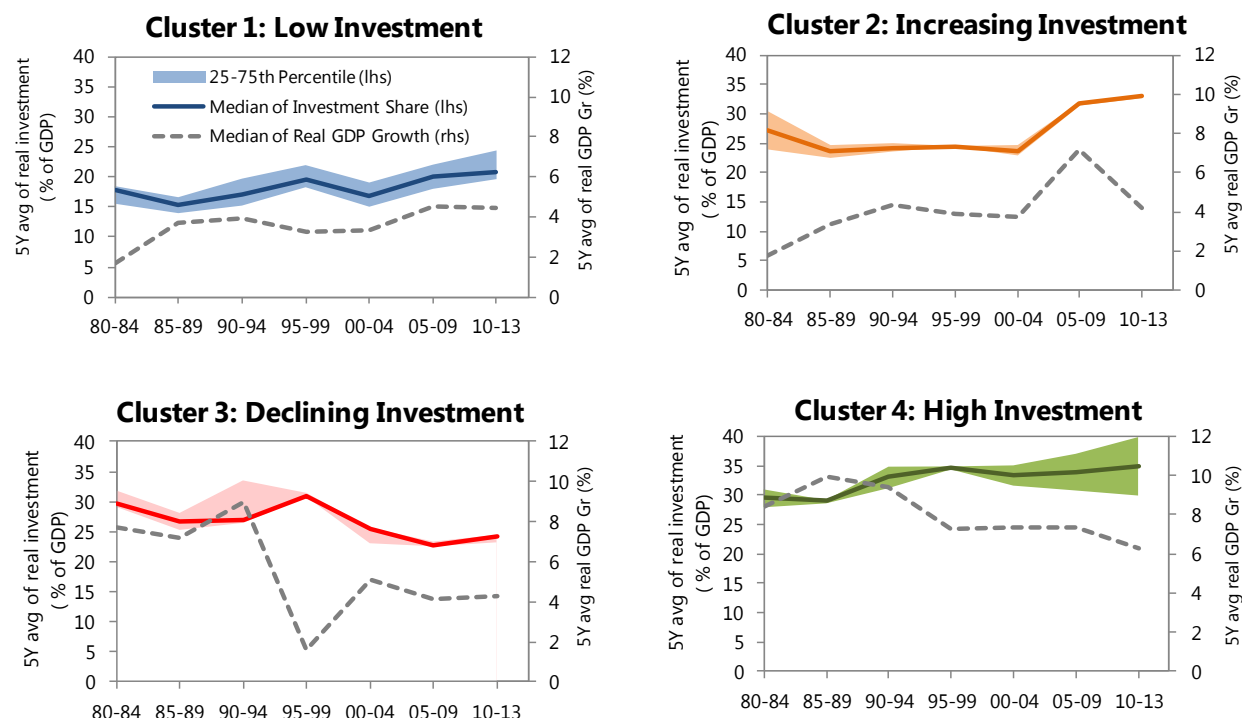

Sources: WEO and IMF staff calculations.

Cluster 1: Argentina, Brazil, Chile, Colombia, Hungary, Israel, Mexico, Pakistan, Peru, Philippines, Poland, South Africa, Turkey, and Uruguay;

Cluster 2: India and Venezuela;

Cluster 3: Hong Kong SAR, Singapore, and Thailand;

Cluster 4: China and Korea.

Figure 5. Clusters Measured by GDP Growth and Consumption

(In percent and in percent of GDP, real terms)
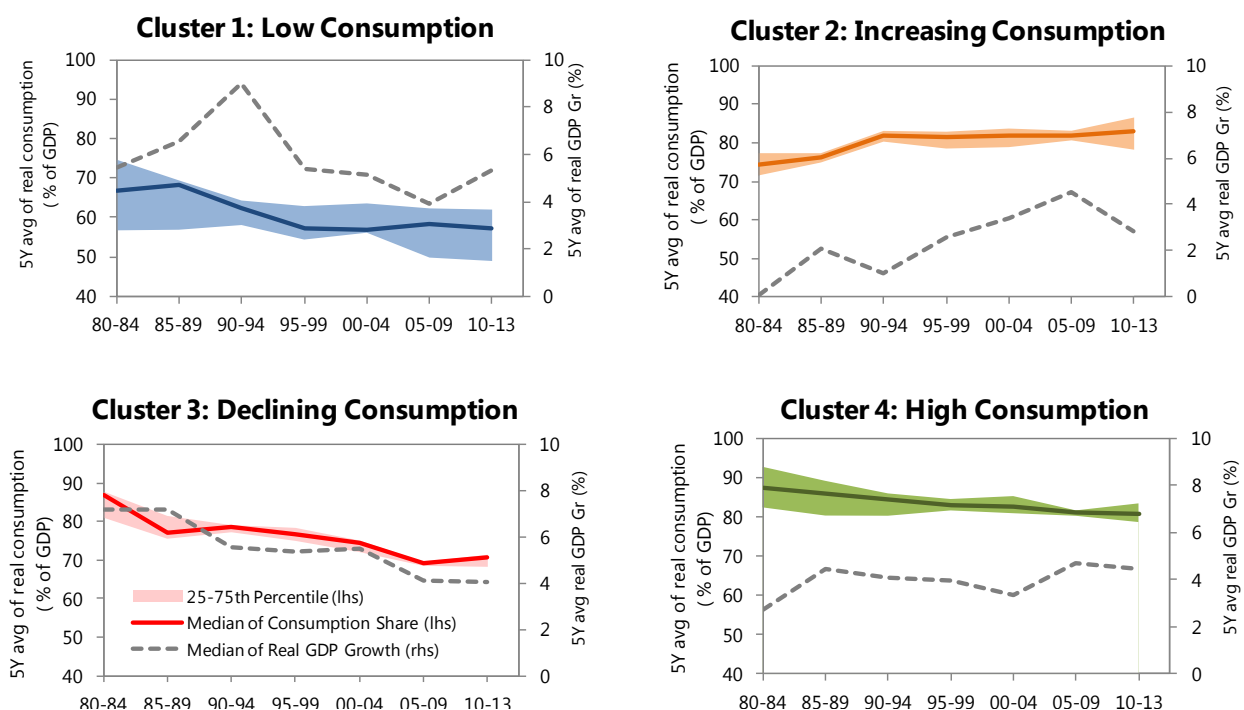

Sources: WEO and IMF staff calculations.

Cluster 1: Chile, China, Mexico, Singapore, and Thailand;

Cluster 2: Hungary, Philippines, Poland, South Africa, Uruguay, and Venezuela;

Cluster 3: India, Hong Kong SAR, and Korea;

Cluster 4: Brazil, Colombia, Israel, Pakistan, Peru, and Turkey. 
relatively high, especially before 2000 (Table 1). The Declining Consumption Group has seen both consumption share and growth rate gradually decline over time. Consumption share in the Increasing Consumption Group has risen gradually to more than 80 percent, and growth rate has been the most disappointing though it accelerated moderately in recent years. For the High Consumption Group, the consumption share is around 85 percent, and growth rate remains stable around 4 percent.

Last but not least, four clusters have been identified using real GDP growth and TFP growth as input variables in the cluster analysis: "Low and Sluggish TFP Growth Group", "Low and Volatile TFP Growth Group", "Moderate TFP Growth Group", and "High TFP Growth Group" (Figure 6). The Low and Sluggish TFP Growth Group has on average $-0.22 \%$ annual TFP growth, and its average real GDP growth rate is $2.5 \%$, the lowest among all groups. The Low and Volatile TFP Growth Group share similar characteristics with the previous group but shows more volatility. The Moderate TFP Growth Group exhibits modest levels of TFP growth and real GDP growth. In the High TFP Growth Group, TFP growth rate is the largest -around 1.6 percent on an annual basis, and its growth rate is also the largest among all groups. Here we choose four groups to present our results in a consistent manner with the other parts of our cluster analysis. In fact, according to the dissimilarity levels, the first two groups can be combined into one "Low TFP Growth Group", and the last two groups can be merged into one "High TFP Growth Group".

\section{Figure 6. Clusters Measured by GDP and TFP Growth}

(In percent)
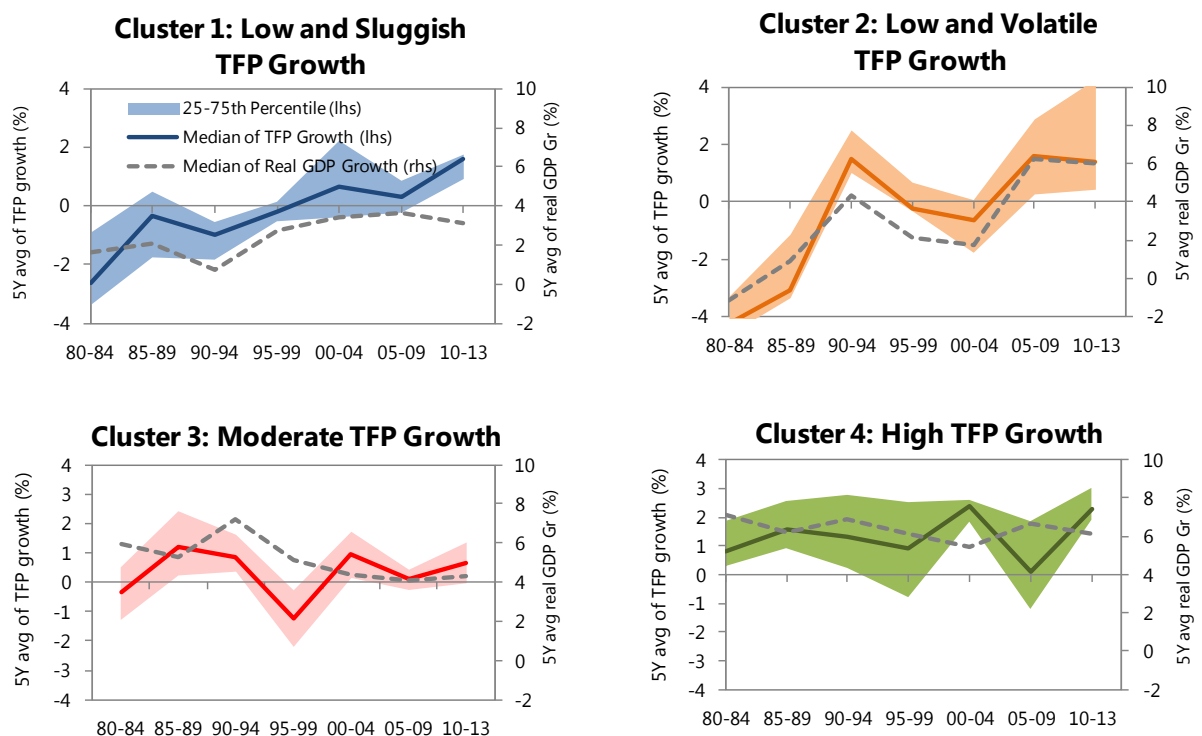

Sources: Penn World Table, WEO and IMF staff calculations.

Cluster 1: Brazil, Hungary, Mexico, Philippines, Poland and South Africa;

Cluster 2: Argentina, Peru, Saudi Arabia, Uruguay, and Venezuela;

Cluster 3: Chile, Colombia, Egypt, Hong Kong SAR, Indonesia, Israel, Korea, Malaysia and Thailand;

Cluster 4: China, India, Singapore and Turkey. 
Putting all the pieces of our cluster results together, we make some interesting discoveries. The investment-growth nexus can be examined by looking at the joint results of growth and investment clusters (Figure 7a). The high growth country is always associated with high investment as the case with China, while low growth countries are always associated with low investments, as these countries appear in the intersection of two sets. Furthermore, when an economy shows declining investment, it also experiences declining growth. In addition, the correlation of real GDP growth and TFP growth clusters is strong: most low growth countries witness slow TFP growth, while high growth countries are always accompanied by high TFP growth (Figure 7b).

Figure 7. Venn Diagrams for Clusters Comparison

\section{7a. Growth Clusters and Growth-Investment Clusters}

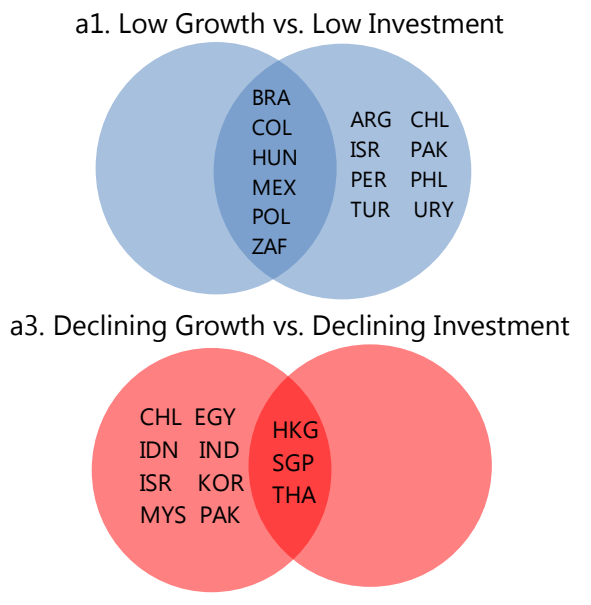

a2. Increasing Growth vs. Increasing Investment
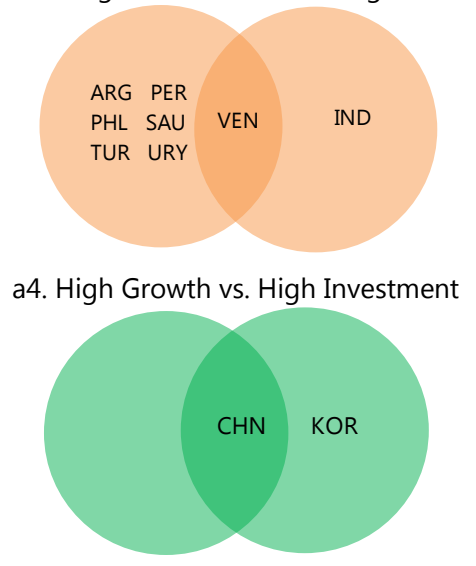

7b. Growth Clusters and Growth-TFP Clusters ${ }^{12 /}$

b1. Low GDP Growth vs. Low TFP Growth

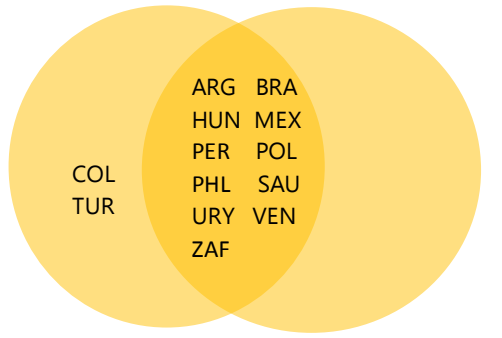

b2. High GDP Growth vs. High TFP Growth

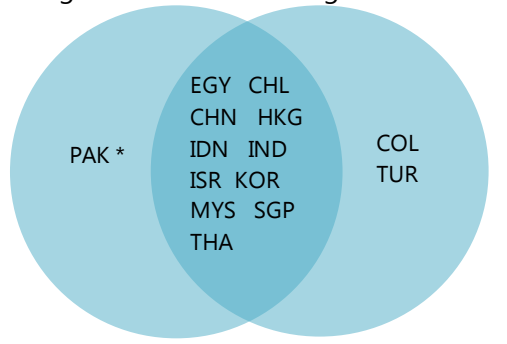

Note: 1/ Here we merge the Cluster 1 and 2 in Figure 3 into a Low GDP Growth group; the Cluster 3 and 4 into a High GDP Growth group. We also merge the Cluster 1 and 2 in Figure 6 into a Low TFP Growth group; the Cluster 3 and 4 into a High TFP Growth group. 2/ Pakistan does not have TFP growth data.

Our results confirm the importance of investment in driving growth in economic development literature. Sala-i-Martin (1997) runs numerous regressions and reports that investment is significantly and positively correlated with growth. Rostow (1959) generalizes five stages of growth: the traditional society, the preconditions for take-off, the take-off, the drive to maturity, and the age of high mass consumption. Countries can have different 
theoretical equilibrium positions for output and investment because they are situating in various stages of growth, or transitioning towards new stages of growth. Based on our results, one can check a particular country's position in each cluster output.

While simplicity is an advantage in our cluster analysis, taking additional information into account is useful to see the whole picture. We refine our results on the investment-growth nexus by looking at the sources of external financing in fueling the investment booms. The type of external financing is classified by comparing the magnitude of five-year cumulative equity and debt inflows to a given country before an investment boom. Our results suggest that investment booms that are financed through raising debt rather than equity can lead to capital over-accumulation and unsustainable growth. As shown in Figure 8, countries with more external debt financing have suffered more severe growth collapse and a sharper increase in the unemployment rate when investment booms have gone bust.

One caveat with our cluster analysis is regarding the persistence and endogeneity of the results. For example, in the growth-investment nexus, over-investment and strong growth is generally followed by under-investment and weak growth during a boom-bust cycle. The issue of endogeneity arises when these separate episodes appear within the same clusters. The question is partially addressed since five-year averages are taken to smooth the trend and the boom-bust cycles will result in higher dissimilarity level in classifying clusters. However, the problem is not completely solved.

Figure 8. Investment Boom-Bust Cycle by External Financing Type ${ }^{1 /}$
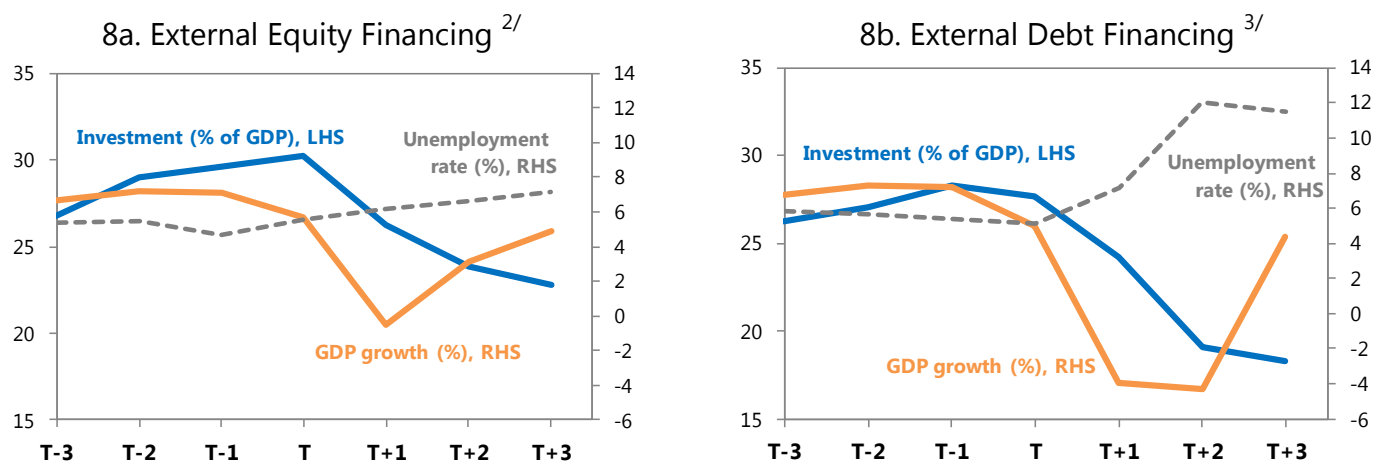

Source: WEO and IMF staff calculations.

$1 / T$ represents a country's investment boom year, defined as the year in which the deviation from the trend of investment share exceeds 2 standard deviations of the cyclical component. The long-run trend is calculated using the HP filter with the smoothing parameter setting at 100 .

2/ External equity financing episodes include Czech Rep. 2008, Colombia 1994, Egypt 1990, India 2007, Indonesia 1997, Malaysia 1997, Pakistan 2006, Poland 1999 and Singapore 1984.

3/ External debt financing episodes include Chile 1981, Mexico 1981, Korea 1997, Philippines 1983, South Africa 2008, Thailand 1996 and Uruguay 1981. 


\section{Refining Economic Convergence Classification}

The clusters identified in our study are useful in understanding economic convergence, and have more explanatory power compared to the traditional geographic classification approach. As illustrated in the cluster result shown in Figure 9a, the GDP per capita of "Low Growth Group" is almost stagnant between 25 and 30 percent of the U.S. level, and only in the last decade the receded trend has been altered. The "Increasing Growth Group" 's path to convergence is uneven, with very unstable GDP per capita growth ranging from 6 percent in good economic times and -3 percent in bad economic times. The state of the economy is so prone to changes that most progress made to achieve high income level is eroded by economic instability. The "Declining Growth Group" 's advancement over the past five decades is remarkable, and average per capita income relative to the U.S. has improved from 15 to 45 percent. The average business cycles of this group are less volatile compared to the first two groups. Therefore, this steady convergence group is able to keep the growth momentum and has seen a growth take-off. China is the only country in the "High Growth Group". It starts from a very low level of development, but extraordinarily high growth rates have shortened the catch-up process.

\section{Figure 9. Convergence of EMs}
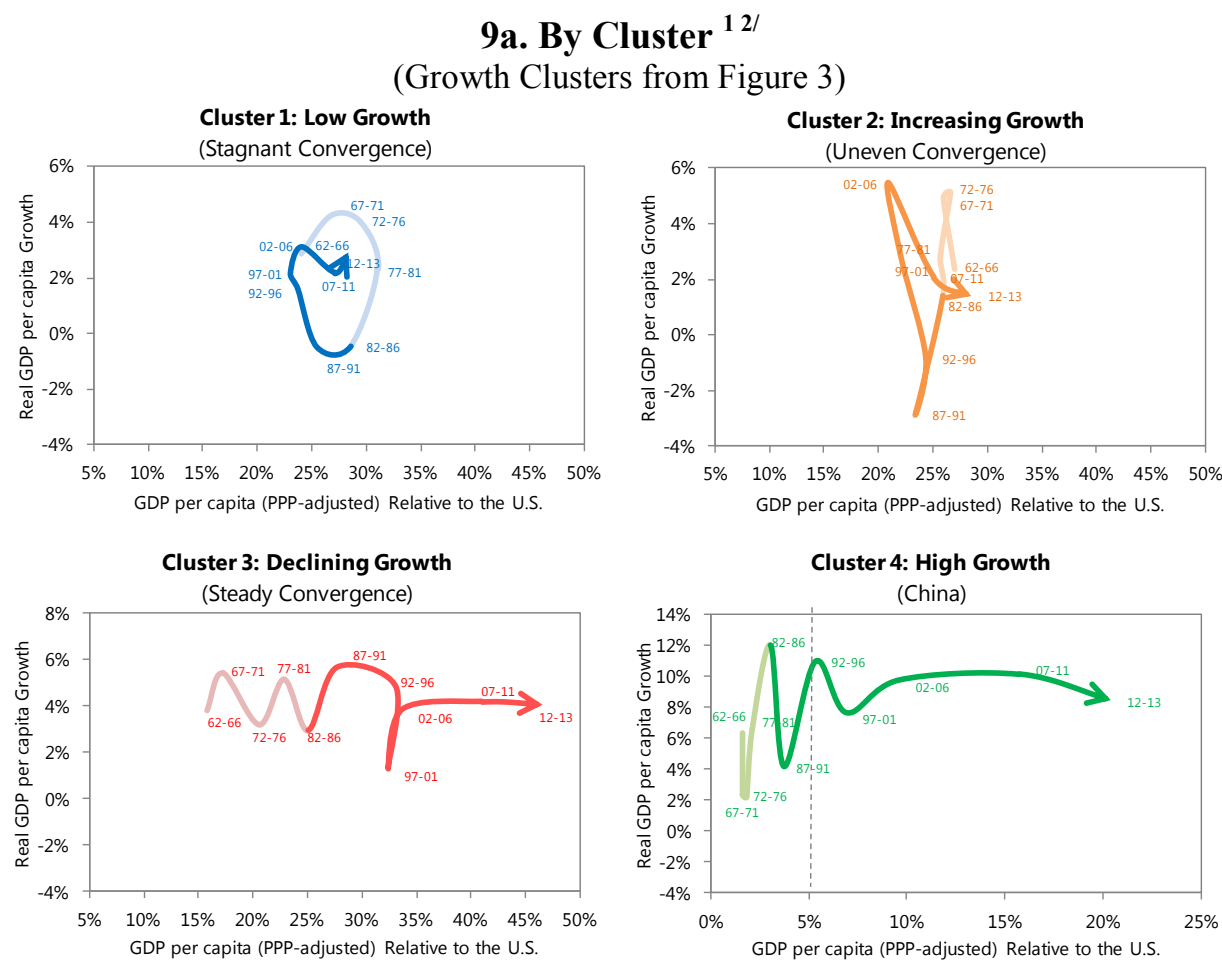


\section{9b. By Region ${ }^{34 /}$}
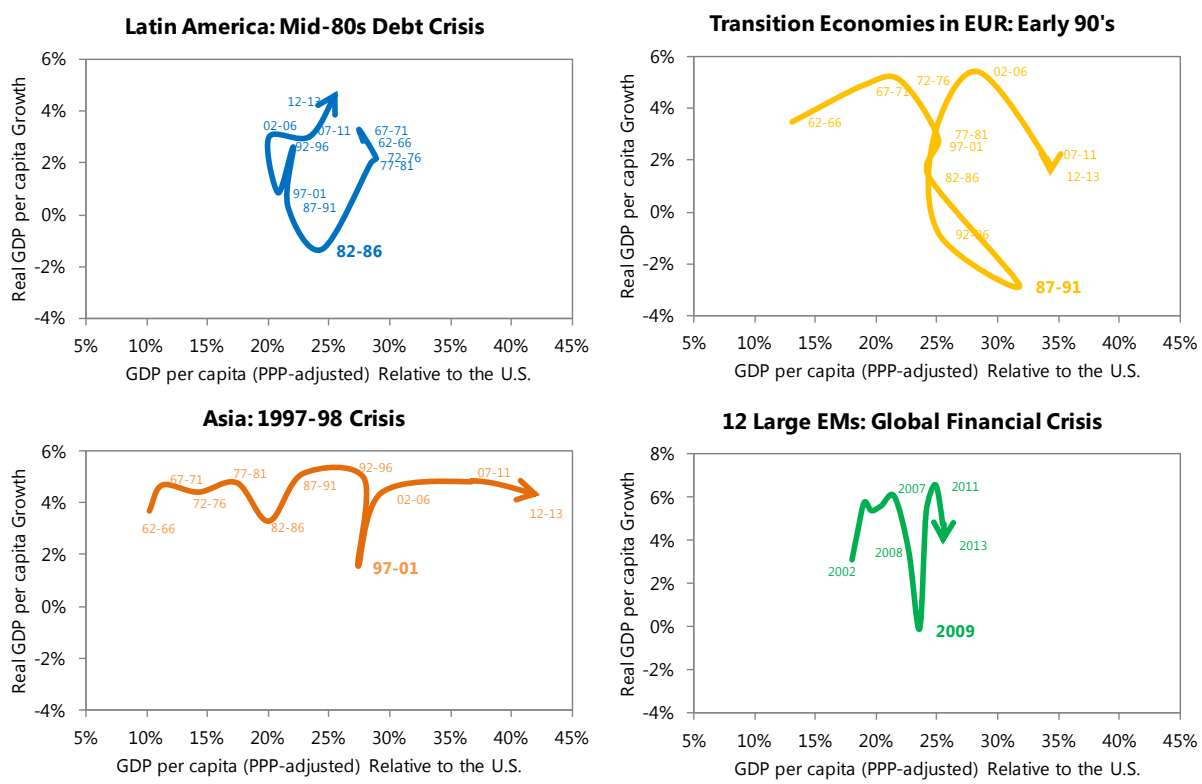

Sources: Penn World Table 7.1, WEO and IMF staff calculations.

1/ Cluster 1: Brazil, Colombia, Hungary, Mexico, Poland, and South Africa;

Cluster 2: Argentina, Peru, Philippines, Saudi Arabia, Turkey, Uruguay, and Venezuela;

Cluster 3: Chile, Egypt, Hong Kong SAR, India, Indonesia, Israel, Malaysia, Pakistan, Singapore, Korea, and Thailand;

Cluster 4: China.

2/ Since our clusters are identified based on sample period of 1980-2013, convergence before 1980 is denoted in lighter colors.

3 / Results from Lipton (2013). The aggregation is expressed as a simple average of countries in each group. The $x$-axis is the 4-

year simple average of real GDP per capita in PPP terms relative to the U.S. The $y$-axis is the 4-year simple average of annual growth of real GDP per capita. 2011-13 data is extrapolated using growth rates from the WEO.

4/ Latin America: Argentina, Brazil, Chile, Mexico, Peru.

Asia: China, Hong Kong SAR, Indonesia, India, Korea, Malaysia, Philippines, Singapore, and Thailand.

Transition economies in EUR: Bulgaria, Czech Republic, Hungary, Poland, Romania, Russia, Slovak Republic, Slovenia, and Ukraine.

Large EMs in GFC: Brazil, Chile, China, Czech Republic, India, Indonesia, Philippines, Poland, Russia, South Africa, Thailand, and Turkey, roughly corresponding to the largest 12 EMs.

Results based on our one-variable cluster output shows a more compelling pattern of convergence than based on geographic regions (Figure 9b). All countries seem to suffer from crises, irrespective of regions: the debt crisis for Latin American countries in the mid-1980s set back development severely; the dissolution of the Soviet Union sent a severe shock to the economies of Eastern Europe and the Commonwealth of Independent States (CIS); the Asian financial crisis was also a serious crisis which led to a huge growth collapse; and the 2008 GFC was even more grave in terms of hurting growth. Our results show that once removing the geographic constraint, countries in the same cluster are more homogenous. For instance, Hungary and Poland grew slowly like some Latin America countries, as shown in Cluster 1; while Chile has seen a steady growth pattern with little fluctuation, like many emerging Asian countries in Cluster 3. 


\section{Understanding Investment-Growth-Unemployment Nexus}

We further explored our two-variable cluster analysis to see if they could offer some insights on investment, growth, and unemployment. Based on the four investment-growth clusters identified in Figure 4, we have found a significant negative relationship between investment level and unemployment in the long run (Figure 10). The four clusters clearly differ from each other in this context. A number of countries in the "Low Investment Group" suffer from high unemployment rates. On the contrary, countries in the "High Investment Group" tend to experience low unemployment rates.

This result is largely consistent with what economic theory would predict. In the long run, one country's saving rate is roughly equal to its investment rate. According to Solow Growth Theory, increases in the saving rate on investment will lead to higher steady state output and therefore a country will witness higher growth (Solow 1956). In addition, according to the Beveridge Curve in Labor Economics, the job vacancy rate and unemployment are negatively correlated. Robust growth creates more jobs, which reduces long-term unemployment (Blanchard and Diamond 1989).

This cluster analysis approach can be extended to other combinations of macroeconomic variables. For instance, one can look at the interaction between jobs and growth by using a labor market indicator and real growth rate data as two inputs. One can also calculate the Misery Index, which is the sum of unemployment and inflation rate, to examine how macroeconomic situation affects people's living standards. Given the theme and length of this paper, we leave these topics for future research.

\section{Figure 10. Unemployment Rate vs. Real Investment Share} (In percent of GDP)

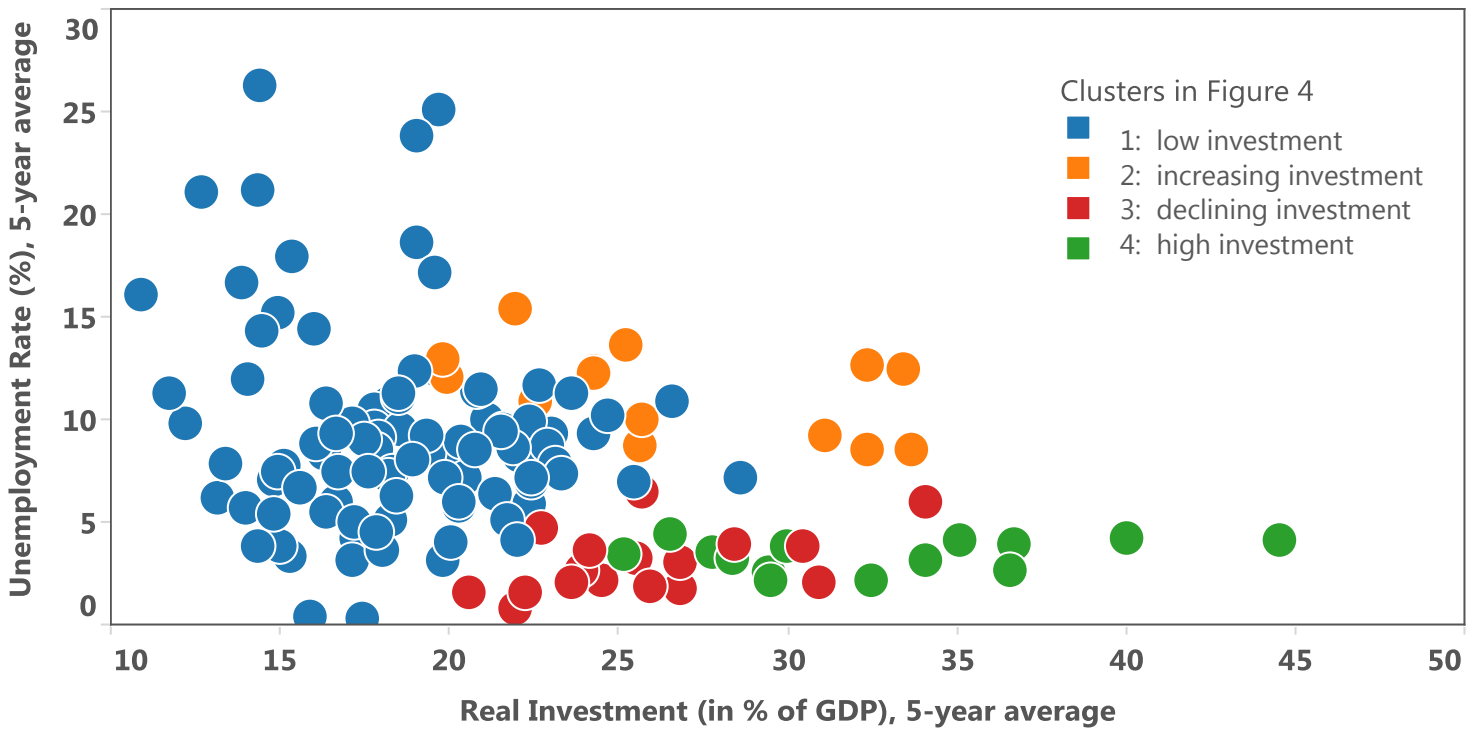

Sources: WEO and IMF staff calculations. 


\section{Recent Performance And TAXonomy of Emerging MARKets}

\section{A. Taxonomy Methodology and Results}

In this section we look at the performance of emerging markets since 2000 and propose a novel taxonomy to classify countries according to their factor endowments as well as external, real, and financial linkages. Unlike the aforementioned cluster analysis in section II, our taxonomy has a short-term focus and utilizes data from 2000 onwards. This also allows us to expand our data sample to 52 economies, including 43 major EMs and 9 Newly Industrialized Economies, covering five different regions. ${ }^{9}$ In this section, six clusters are identified for each indicator using Ward's linkage method, and then the cluster numbers are reduced to three based on the authors' judgment and sensitivity analysis results. Kernel density estimation is used as robustness test to ensure correctness of the countries in different clusters.

Recently, emerging markets are slowing down due to both external and domestic factors, as shown in Cubeddu et al. (2014). This prompts us to classify the taxonomy from both domestic and external angles. From the domestic angle of our taxonomy, we examine driving forces of growth from the supply and demand side of the economy. From the supply side, we decompose total real output growth into the following sources: physical capital contribution, labor contribution, and TFP contribution. We then calculate the ratios of each component's contribution to total growth for each country and conduct a cluster analysis using the median values of annual data during 2000-2013 for each country. The taxonomy output is presented in Figure 11. The higher the rank is, the more "capitaldriven", "labor-driven" and "technology-driven" the country is. On the demand side, we decompose total real output growth similarly into consumption contribution, investment contribution, and net exports contribution. We apply the same cluster methodology to demand side indicators. The higher the rank is, the more "consumption-led", "investmentled" and "export-led" the country is.

\footnotetext{
${ }^{9}$ The complete country list for taxonomy analysis is shown in Appendix Table 3. Underlying data sources are listed in Appendix Table 4.
} 
Figure 11. Taxonomy Output of Domestic Indicators

(Measured by each indicator's contribution to GDP growth as percent of GDP growth)

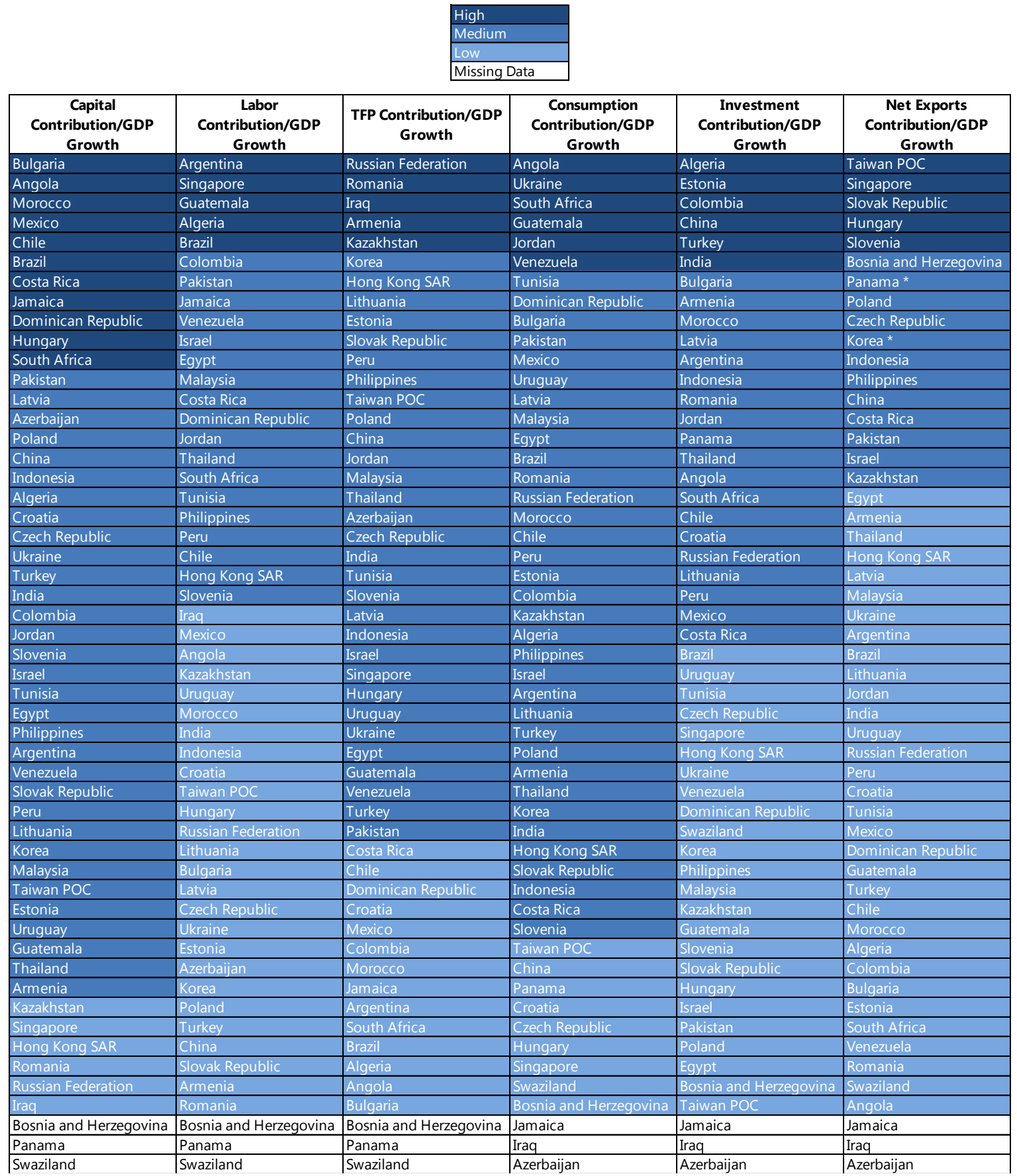

Sources: Total Economy Database, WEO and IMF staff calculations.

* represent countries that showed trade deficit through 2000-2012 period but its net exports had been improving and therefore contributing positively to GDP growth.

Next, we move to the external angle of our taxonomy, since external factors are found to have positive and statistically significant contributions to growth surprises of most EMs in recent years (Fayad and Perrelli 2014). We grouped countries based on their financial 
openness, trade openness and linkages, terms of trade growth, and net commodity dependence (Figure 12). For each variable, we classified the sample into three groups based on the cluster analysis results. According to the data, Hong Kong SAR and Singapore are with extraordinarily high levels of financial and trade openness compared with the rest of EMs sample. Based on our measure, only 6 economies with relatively high levels of financial openness are in the top-tier in contrast to 23 economies in the bottom-tier. Distribution of trade openness is more uniform among EMs, with about one third of economies in each category. Distribution of terms of trade growth looks similar, but features more economies belonging to the middle category. Only 9 EMs are large net commodity exporters, while 31 economies are running either a small net commodity export surplus or a net commodity export deficit.

Figure 12. Taxonomy Output and Distribution of External Indicators

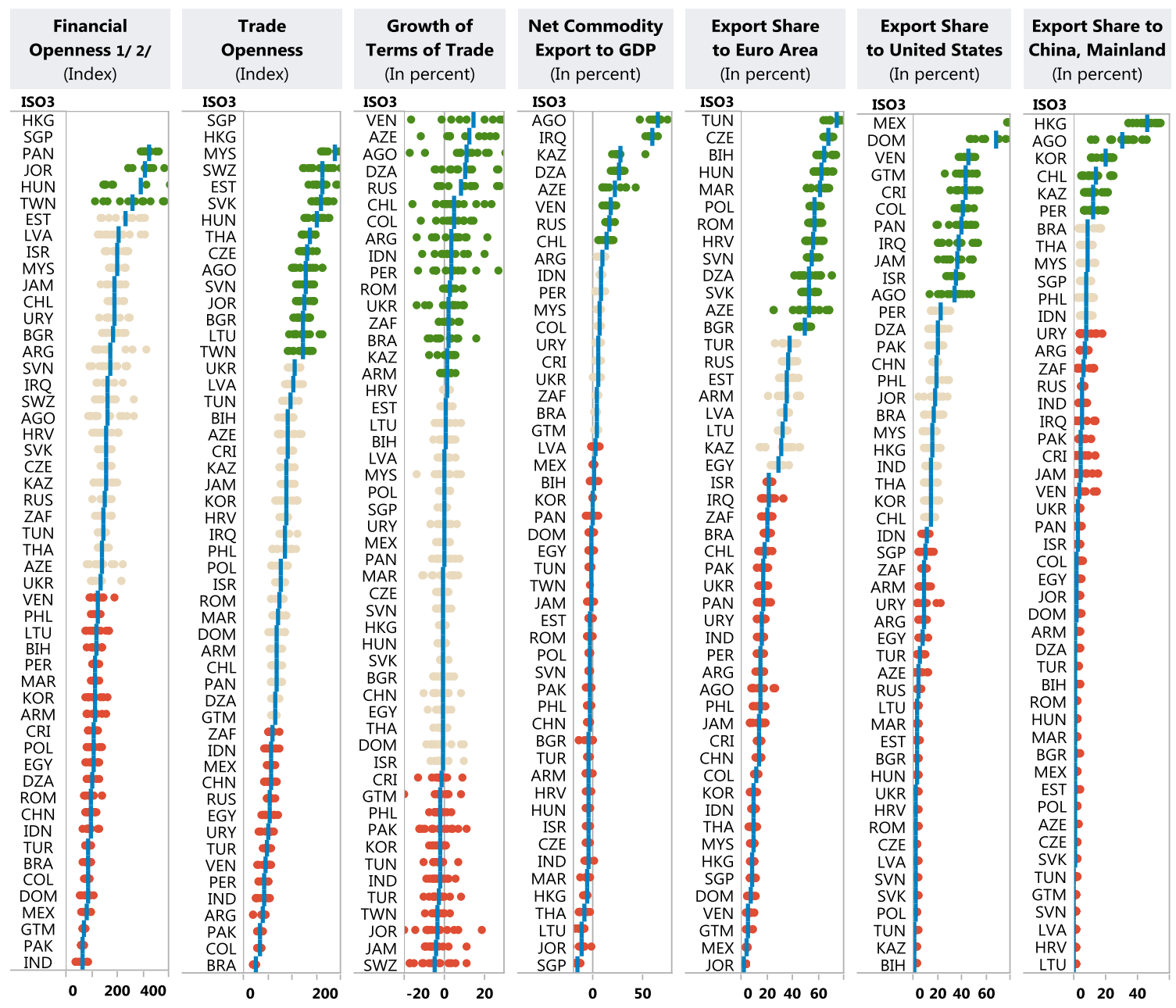

Sources: IFS, Lane and Milesi-Ferretti (2007), WEO and IMF staff calculation.

$1 /$ HKG and SGP are the financial centers with very high financial and trade openness indices.

2/ Dots represent countries' annual data distribution during 2000-2012/2013; Blue lines represent countries' period averages.

3/ Green, grey, and red colors indicate top, middle, and bottom groups. 
In addition, we calculated each EM's trade linkage with three major world trade partners: the Euro area, the U.S., and China. Each taxonomy has three groups: for export to the Euro area, cutoff points for high, medium, and low linkages are 49 percent and 29 percent; for export to the U.S., cutoff points are 34 percent and 14 percent; for export to China, cutoff points are 12 percent and 4 percent. On average EMs have stronger trade ties with the Euro area and the U.S. than their trade ties with China. However, this relationship is evolving as China plays an increasingly important role in the global supply chain. We will expand this discussion later together with Figure 16.

\section{B. Explaining the Degree of Economic Recovery}

Now we turn to investigate what implications our taxonomy can offer in explaining the trends since 2000. Using our domestic angle taxonomy results, the speed and degree of economic recovery since the GFC can be explained by our domestic angle taxonomy to the extent whether an economy is primarily consumption-led or investment-led. When the crisis began, EMs were hit badly, with growth rates of all output components moving towards negative territory. This is illustrated in the growth dynamics under high frequency (Figure 13a). After global trade collapsed, EMs' growth decomposition has shown that net exports contributed negatively to growth for four consecutive quarters. Consumption and investment were weak as well, adding more downward pressure on growth. The degree of EMs' economic deteriorations were different across geographic regions (Figure 13b). Emerging Europe had the sharpest real output decline among all regions because it has closer trade and financial ties with AMs. Other regions were not immune to the effects of the recession. Compared to pre-crisis growth, post-crisis growth has lowered by 4.3 percentage points for Emerging Europe and 1.5 to 2.6 percentage points for other regions. EMs rebounded relatively quickly overall in the post-crisis period, though recovery speed varied by geographic region. Our taxonomy indicates that countries that are mainly consumption-led rebounded the slowest and weakest (Figure 13c). The high consumption-led group, which includes a set of six countries, had the deepest recession, and its recovery was the weakest among all groups. On the other hand, countries that are mainly investment-led rebounded the fastest and strongest (Figure 13d). The high investment-led group, which includes another distinct set of six countries, had the mildest recession, and its recovery was the most robust among all groups. Post-crisis growth rates of the high investment-led group have always excelled that of the medium and low investment-led groups. ${ }^{10}$ One conjecture to explain this phenomenon is that economic agents can adjust consumption freely based on observed shocks, while it is more difficult to do so for investment due to capital irreversibility and adjustment costs. Therefore investment can stabilize the economy in the short run and promote growth in the long run.

\footnotetext{
10 We have performed robustness tests for output recovery dynamics by consumption-led and investment-led degree in the $1980 \mathrm{~s}$ and $1990 \mathrm{~s}$. The results are similar.
} 


\section{Figure 13. Growth and Recovery of EMs}

13a. Sources of Growth from the Demand Side (In percent, 4-quarter simple moving average ${ }^{1 /}$ )

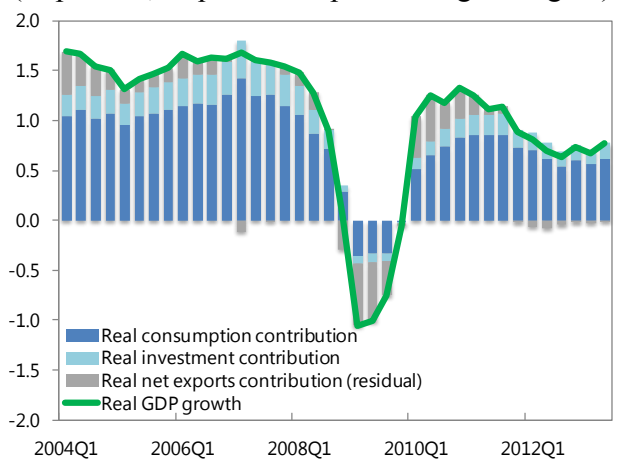

13c. By Consumption-led degree

(In percent, seasonally-adjusted quarterly GDP growth)

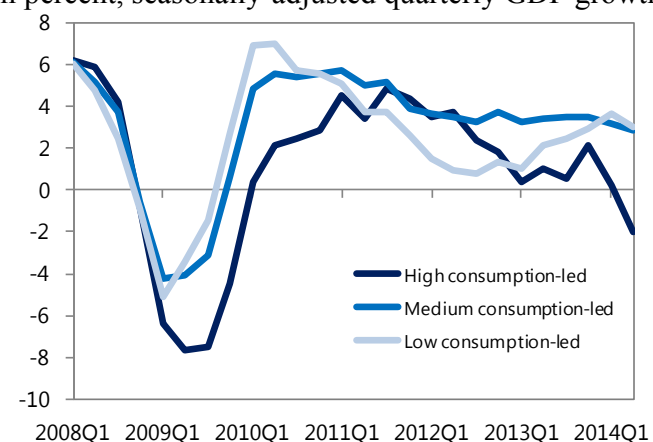

13b. Median of EMs' Real GDP Growth by Region (Average seasonally-adjusted quarterly GDP growth) ${ }^{23 /}$

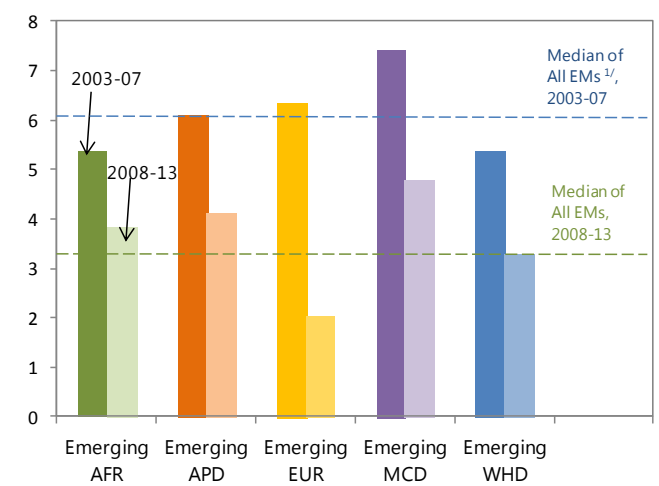

13d. By Investment-led degree (In percent, seasonally-adjusted quarterly GDP growth)

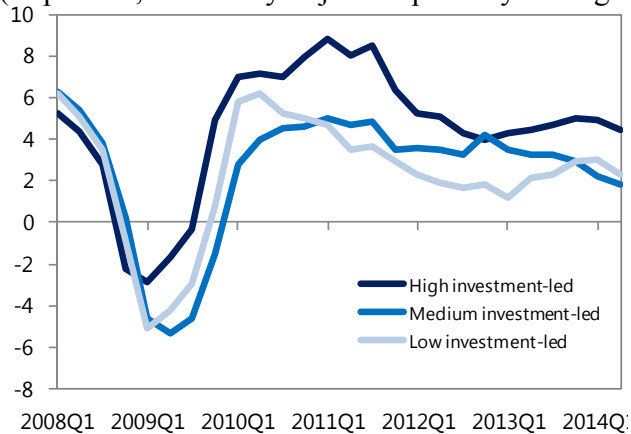

Sources: Haver Analytics, Penn World Table 8, WEO and IMF staff calculations.

1/ The Haver database covers 35 major EMs' quarterly data (some data were seasonally adjusted by the authors).

2/ All EMs refers to the EMs list in Appendix Table 1.

3/ AFR=Africa, $\mathrm{APD}=$ Asia and Pacific, EUR=Europe, $\mathrm{MCD}=$ Middle East and Central Asia, WHD=Western Hemisphere.

\section{The Impact of External Factors on Growth}

What's the role of external factors on growth and how do economies with different fundamentals respond to external shocks? Based on our external angle taxonomy, we construct an overall index of external factors to address this question. The overall index is a composite of four indicators: financial openness, trade openness, terms of trade growth, and net commodity export to GDP. For each economy i, component $j$, we standardize the subindex using a global min-max scale:

index $_{i j}=\frac{\text { value }_{i j}-\min _{j}}{\max _{j}-\min _{j}}$

so that it's between 0 and 1 . Then we apply principal component analysis to endogenize the weights of the sub-indices by taking the squared factor loadings of the first principal 
component. Finally, a unique index will be assigned to each country by taking the weighted averages of its four components. The higher the index is, the more the country is exposed to the world economy. Next, we divide our sample into tertiles and examine the impact of external factors on growth, before and after the Global Financial Crisis.

Figure 14a clearly shows how severe the GFC was in terms of disrupting growth. All three groups experienced significant slowdowns. What's more interesting is that the degree of slowdown is positively correlated with the degree of the external factor. The top tertile has seen post-crisis growth rate dropped by 6.4 percentage points from 8.4 percent to 2.0 percent, while the middle tertile's growth rate dropped by 3.2 percentage points from 5.8 percent to 2.6 percent and the bottom tertile's growth rate dropped by 2.3 percentage points from 6.6 percent to 4.3 percent.

A similar relationship can be found in growth surprises. Following Fayad and Perrelli (2014), we measure growth surprises as the difference between the actual real GDP growth rate for country $i$ in year $t$ and the projected real GDP growth rate for that same country one-year ahead, as published in the IMF's WEO of the previous year. As Rey (2013) argues, the global financial cycle can be partly explained by a common global factor. Motivated by her work and the macro-financial linkages, we found that the degree of growth surprise is positively correlated with the degree of the external factor. Probably driven by the global factor, growth surprise is negative for all three groups during 2008-2012 (Figure 14b). But the extent of growth surprise varies substantially: for the bottom tertile with the least external exposure, growth surprise is -0.5 percentage points. For the middle tertile, the number is -1.1 percentage points. For the top tertile, the growth surprise is -2.7 percentage points, about twice as large as the surprise on the middle tertile and five times as large as the surprise on the bottom tertile.

Figure 14. The Impact of External Factors on Growth
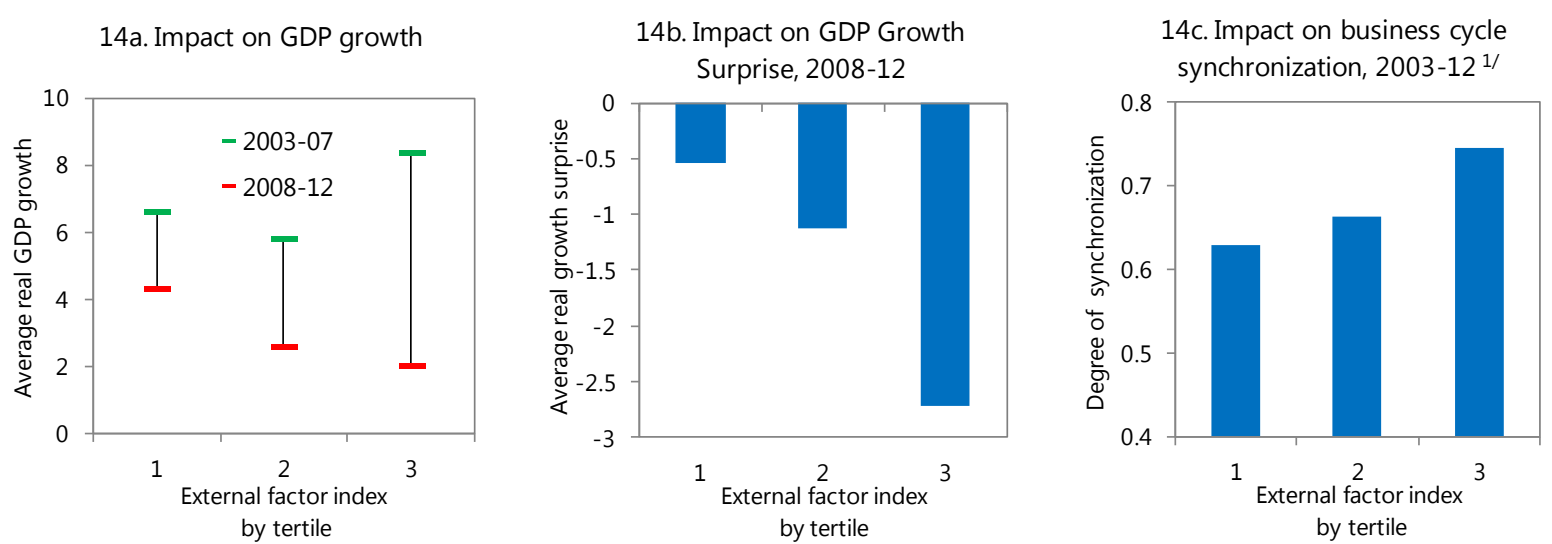

Sources: WEO, Lane and Milesi-Ferretti (2007) and IMF staff calculations.

$1 /$ The degree of business cycle synchronization is defined as the correlation between one country's real GDP growth rate and world real GDP growth rate. 
Lastly, we investigate the degree of business cycle synchronization since the assumption is that the higher the external factor is for a given country, the more closely its business cycle should co-move with the world economy. The result in Figure 14c supports our assumption: the degree of business cycle synchronization is positively correlated with the degree of the external factor. For the bottom, middle, and top tertiles, their output correlations with global output are $0.63,0.66$, and 0.75 respectively.

\section{The Role of Openness on Growth}

EM's successful economic performance can also be partly attributed to the commodity price boom story. Favorable terms of trade change has helped commodity-exporting EMs in boosting growth, especially for large net commodity exporters (Figure 15). Average elasticity of EM commodity exporters' growth to term of trade changes is about 0.14 and statistically significant. The average impact of terms of trade changes on non-commodity-exporters is minimal and statistically insignificant (Cubeddu et al. 2014). When growth of terms of trade is adjusted by trade openness, we find a positive relationship on growth as well. This means terms of trade shocks are magnified through the trade channel: the more open in international trade for a commodity exporter, the more likely it is for the country to enjoy the windfall on growth. Therefore, one can look at our external angle taxonomy (trade openness, growth of terms of trade, and net commodity export to GDP) to examine how much a particular country benefits from the commodity boom.

As EMs are more integrated with the world economy over the last decade, global imbalances have come a hot topic in intellectual debate. Gourinchas and Rey (2013) provide an overview of the recent developments of the literature on external adjustment, global imbalances and valuation effects. Prior to the Global Financial Crisis, increased and persistent current account deficits and surpluses have caught people's attention. As Figure 15 shows, some EMs have incurred considerable cumulative current account deficits over the period of 20032007. When the crisis hit, the damage was amplified by the degree of financial openness: those countries with larger deficits and greater financial openness suffered the most growth slump. This is because after the crisis deficits countries need to spend more effort repairing balance sheet, reducing leverage and cutting excessive financial interconnectedness. 
Figure 15. The Impacts on Growth from Commodity Boom and Global Imbalances Adjusted by Openness Measures
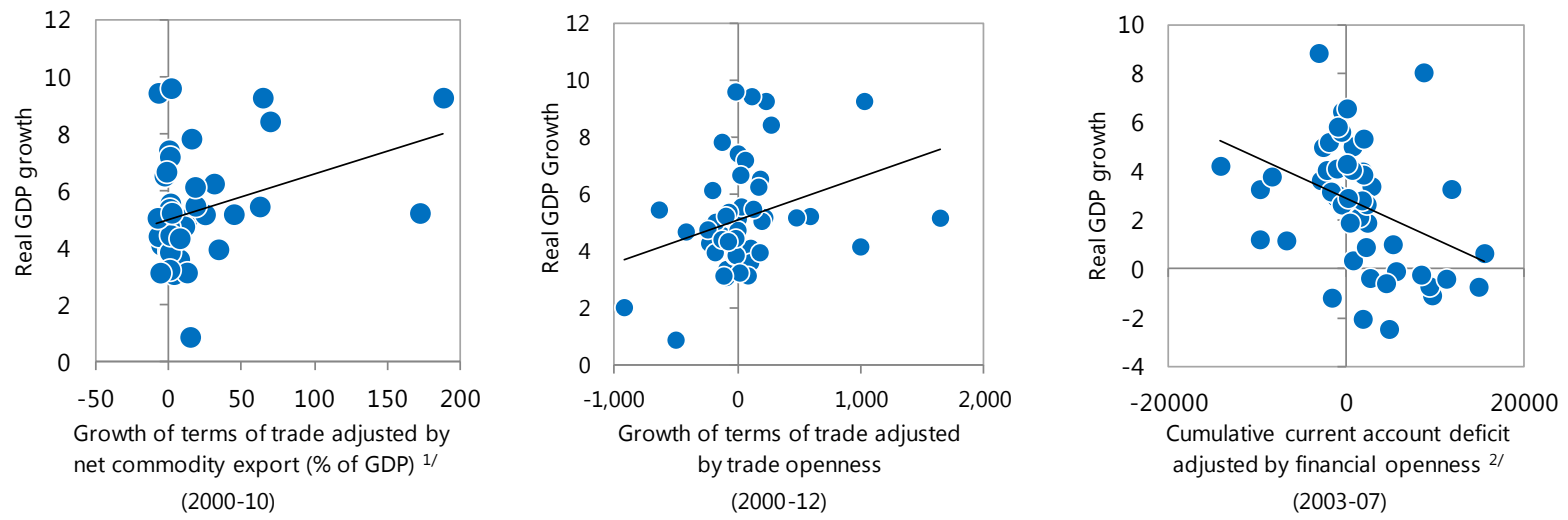

Source: WDI, WEO and IMF staff calculations.

1/ Angola and Venezuela are omitted for presentation purpose given the magnitude of their $\mathrm{x}$-axis variables.

2/ Hong Kong SAR and Singapore are omitted for presentation purpose given the magnitude of their financial openness.

\section{E. Trade Linkages and Spillover Effects}

How do trading partners matter for economic growth? Figure 16a shows an increasingly strong trade tie of EMs with China. In the 1990s, the average EMs' exports to the Euro area, the U.S., and China as percentage of exports to the world were 27.3, 17.3, and 2.3 percent respectively. Ten years later, average EMs' exports to the U.S., Euro area, and China became 28, 17.5, and 5.4 percent. While EMs' average export shares to Euro area and U.S. remained strong and stable, their average export share to China has increased by 132 percent. Using the top taxonomies which have strong trade linkages to the Euro area, the U.S., and China, we calculated summary statistics on the simple average of real growth rates of those top taxonomies. Results in Figure 16b indicate that countries who trade more with China on average experienced faster growth than countries who trade more with the other two economies. This fact was more pronounced in the post-crisis period, as the Euro area's trading partners have witnessed their growth almost faltering. A recent paper by Mishra et al. (2014) has complemented our results. The authors study the market reactions of 21 emerging markets to the U.S. Federal Reserve's policy announcements relating to reducing its asset purchase programs in 2013 and 2014. They find that the stronger trade linkage with China (measured by total trade with China to its own GDP), the less market volatility a country will experience during the Fed tapering talk, ceteris paribus. 


\section{Figure 16. Trade Linkages and Growth}

\section{6a. Trade Linkages by Export Destination}

(Share of exports of goods to each destination as percentage of exports to the world)

$0 \square$

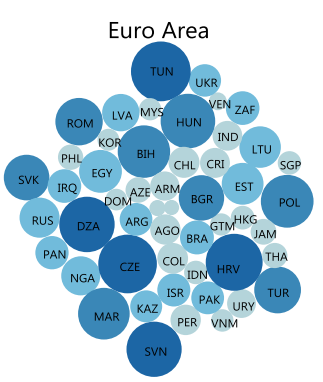

Average of annual data during 1990-99

United States

China
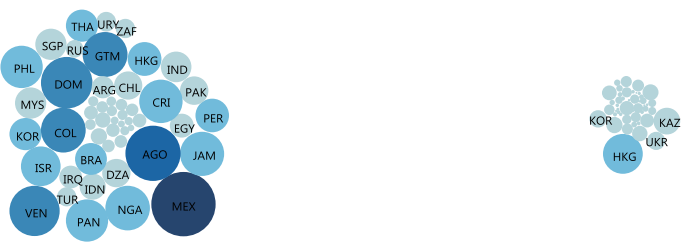

Average of annual data during 2000-13

United States

China
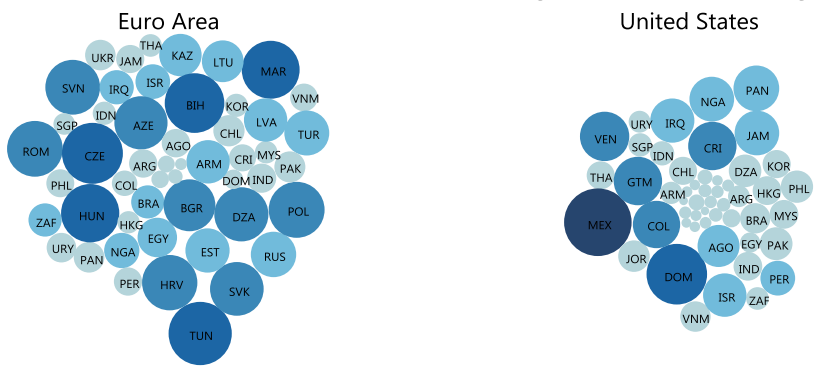

Avg of all EMs,

16b. Trade Linkages and Real GDP Growth

avg Real GDP growth (\%), 2000-07

Avg Real GDP growth (\%), 2008-13

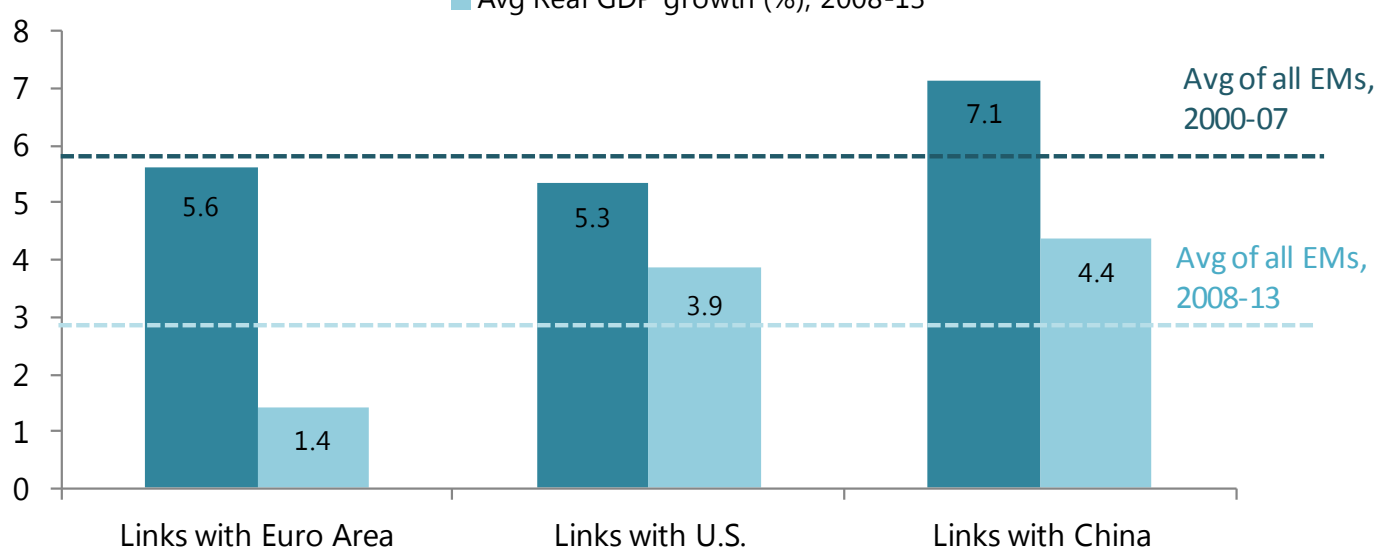

Sources: IFS, WEO and IMF staff calculations.

$1 /$ Only countries in the top clusters are included in the calculation (Figure 12)

2/ EMs links with China: $A G O, C H L, H K G, K A Z, K O R, P E R$

3/ EMs links with the U.S.: AGO, COL, CRI, DOM, GTM, ISR, JAM, MEX, PAN, VEN (IRQ is excluded due to missing data)

4/ EMs links with Euro Area: AZE, BGR, BIH, CZE, DZA, HRV, HUN, MAR, POL, ROM, SVK, SVN, TUN

5/ All EMs refer to Appendix Table 3, excluding China, Swaziland and Taiwan POC.

6/ The average of all EMs' real GDP growth before crisis was mainly driven by oil exporters including Angola, Azerbaijan and Kazakhstan.

7/ Before the GFC, average real GDP growth rates for EMs with strong trade links to China are statistically higher; after the GFC, average real GDP growth rates for EMs with strong trade links to Euro Area are statistically lower. Results are based on the unpaired two-sample t-test. 


\section{Conclusions}

Emerging market economies' rise over the last five decades has greatly reshaped the global economic landscape. Their contribution to world output makes them a significant economic powerhouse that cannot be ignored. We are contributing to the literature by exploring emerging market heterogeneity and identifying clusters and creating a simple taxonomy based on EMs' fundamentals. The clusters identified in our study point to four distinct patterns of long-term economic convergence and have more explanatory power in understanding convergence than the traditional geographic classification approach. We found an interesting interaction between long-term growth and investment clusters: investment clusters are highly correlated with growth clusters, and this indicates that investment is a necessary but not sufficient condition for growth. In addition, economic growth and productivity improvement tend to go hand in hand, according to our TFP growth and real GDP growth clusters. On the investment-growth-unemployment nexus, on average countries in the high investment-growth group tends to have low unemployment rates, while countries in the low investment-growth group are likely to have high unemployment rates.

In recent years, Emerging Market Economies have seen a prolonged boom period before the Global Financial Crisis. EMs rebounded relatively quickly overall in the post-crisis period, but the growth has slowed recently. With the taxonomy provided in this paper, one can examine the heterogeneity of EMs from factor endowments, external, real, and financial linkages. Results have shown that the degree of economic recovery can be explained by the source of growth: countries that are mainly investment-led rebounded the fastest and strongest, while countries that are mainly consumption-led rebounded the slowest and weakest. The external factors play an important role to explain growth dynamics pre and post Global Financial Crisis: the degree of economic slowdown, growth surprise, and business cycle synchronization are all positively correlated with the degree of our external factor index. To study the impact on growth from booms in commodity prices and global imbalances, we look at terms of trade changes adjusted by commodity export and trade openness measures, and cumulative current account deficits adjusted by financial openness. Results suggest that increased openness has an amplifying effect in transmitting terms of trade shocks and external adjustment pressure on growth. In addition, we emphasized the spillover effects from trade linkages. One country's growth can benefit significantly from, or dragged by its trading partners, depends on who you trade with.

Looking forward, continuing convergence to high income level for EMs will be more challenging and is not guaranteed. Tailored policy actions are needed to take into account the heterogeneity in the EM universe beyond the traditional geographical and income approach. The clusters and taxonomy presented in this paper can be used as a reference to design both near and long-term policies. 


\section{Cluster Methodology}

\section{APPENDIX}

Ward's method starts with $n$ clusters (in our case $n=25$ ) of size 1 and stops when all the observations are merged into one single cluster. In each step, the observations are combined to minimize the errors sum of squares (or equivalently, maximize the R-square) from the group centroid. We conduct a twostage clustering approach in section II: in the first stage, we obtain cluster IDs for each observation within a given country, hence a country will have a series of 7 cluster IDs in our case; in the second stage, all the cluster IDs of each country are utilized to determine a single cluster ID for that country. The final output is shown in the figure below. Note that the numbers of clusters is chosen at the discretion of the dissimilarity level. We believe four is an appropriate number that distinguishes clusters among EMs and allows good interpretation of similar characteristics within each cluster.

\section{Figure 1. Dendrogram to Determine Growth Clusters}

(Measured by real GDP growth, input for Figure 3)

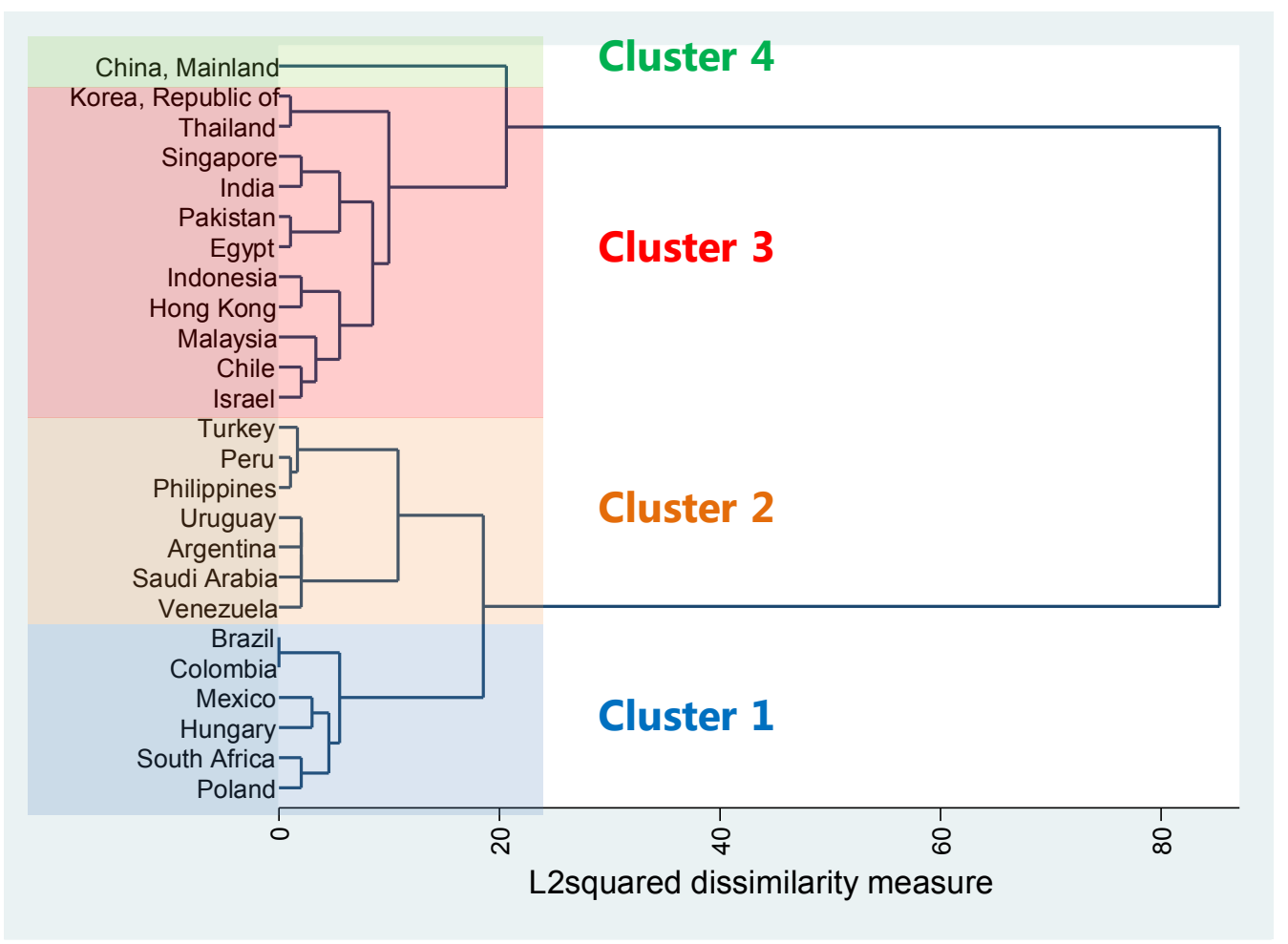

Note: This dendrogram represents the relationship of dissimilarity levels among countries based on real GDP growth over the period of 1980-2013, using Ward's Linkage clustering algorithm. The horizontal axis represents the distance of dissimilarity among clusters. The longer the horizontal line is, the more dissimilar of the underlying countries or clusters are compared with others. The vertical axis represents one country or cluster. Each junction of two countries or clusters is represented by merging two horizontal lines into one. In the above chart, China shows the highest level of dissimilarity among all countries. If we force the cluster number to be two, cluster 1 and 2 will be combined into one group, and cluster 3 and 4 will be combined into another group, as they display similar growth patterns. 


\section{Taxonomy Methodology}

For each domestic indicator, period medians of each country are used for the analysis, after excluding the outliers - because the observations are very volatile, especially when GDP growth is very close to zero. We define outliers as observations that fall out of 5th-95th percentile range of the entire cross country sample during a 3-year crisis window. The crisis window is defined as the three years preceding the crisis (including banking, currency and debt crises). Crisis data is from Laeven and Valencia (2012). Based on these criteria, around 1.3 to 2.8 percent of observations are dropped for the domestic indicators. This ensures that taxonomy result reflects a country's overall trend in recent years. For the supply side variables, we conduct growth accounting by assuming that output follows the standard Cobb-Douglas function:

$Y_{t}=A_{t} K_{t}^{\alpha} L_{t}^{1-\alpha}$

where $\mathrm{Y}_{\mathrm{t}}, \mathrm{K}_{\mathrm{t}}, \mathrm{L}_{\mathrm{t}}$, At represent period t output, physical capital stock, employed labor force, and total factor productivity (TFP), respectively. From equation (1), we can further decompose growth in log forms as follows:

$\Delta y=\Delta a+\alpha \Delta k+(1-\alpha) \Delta l$

Capital contribution to GDP growth is the sum of ICT (Information and Communication Technology) and non-ICT capital contributions to GDP growth, which are directly from the Total Economy Database (The conference board 2014). Labor contribution to GDP growth has taken into account of the products of labor quantifies and labor quality. Total Factor Productivity (TFP) contribution to GDP growth is a residual, which accounts for effects in total output growth not caused by labor or capital inputs.

For the demand side variables, the contribution of a component to GDP growth is calculated as the real growth rate of this component weighted by its share in total real GDP in the previous year.

Contribution of $\mathrm{X}$ to GDP growth $=\left(\mathrm{X}_{\mathrm{t}} / \mathrm{X}_{\mathrm{t}-1}-1\right) * \frac{\mathrm{X}_{\mathrm{t}-1}}{\mathrm{GDP}_{\mathrm{t}-1}} * 100$

Consumption and investment contributions to GDP used WEO's annual consumption, investment and GDP output data in real terms. Contribution of net exports is calculated by subtracting the contributions of exports from the contribution of imports, in order to capture the net trade impact on GDP growth (Lequiller and Blades 2006). To preserve the sign of each factor's contribution, we take absolute values of GDP growth.

$\mathrm{X}$ Contribution / GDP growth $=\frac{\text { contribution of } \mathrm{X} \text { to GDP growth (in percentage points) }}{\mid \text { GDP growth rate (in percentage points) } \mid}$

Different from the domestic taxonomy indicators, for each external indicator, the period simple averages are used for clustering instead of period medians. This is because the external taxonomy indicators' values are quite stable across the sample period. 
Table 1. Country Classification by Economic Group

\begin{tabular}{|c|c|c|c|c|}
\hline \multirow{2}{*}{$\begin{array}{c}\text { Advanced Economies } \\
\text { (AMs) } \\
26 \text { Countries }\end{array}$} & \multicolumn{2}{|c|}{$\begin{array}{c}\text { Emerging Market Economies } \\
\text { (EMs) } \\
89 \text { Countries } \\
\end{array}$} & \multicolumn{2}{|c|}{$\begin{array}{c}\text { Low-Income Countries } \\
\text { (LICs) } \\
71 \text { Countries } \\
\end{array}$} \\
\hline & Albania & Kuwait & Afghanistan & Maldives \\
\hline Austria & Algeria & Latvia & Bangladesh & Mali \\
\hline Belgium & Angola & Lebanon & Benin & Mauritania \\
\hline Canada & Antigua \& Barbuda & Libya & Bhutan & Moldova \\
\hline Cyprus & Argentina & Lithuania & Bolivia & Mongolia \\
\hline Denmark & Armenia & Macedonia, FYR & Burkina Faso & Mozambique \\
\hline Finland & Azerbaijan & Malaysia & Burundi & Myanmar \\
\hline France & Bahamas, The & Mauritius & C.A.R. & Nepal \\
\hline Germany & Bahrain & Mexico & Cambodia & Nicaragua \\
\hline Greece & Barbados & Montenegro & Cameroon & Niger \\
\hline Iceland & Belarus & Morocco & Cape Verde & Nigeria \\
\hline Ireland & Belize & Namibia & Chad & Papua New Guinea \\
\hline Italy & Bosnia and Herzegovina & Oman & Comoros & Rwanda \\
\hline Japan & Botswana & Pakistan & Congo, Dem. Rep. of & Samoa \\
\hline Luxembourg & Brazil & Panama & Congo, Republic of & São Tomé and Príncipe \\
\hline Malta & Brunei Darussalam & Paraguay & Cote D'Ivoire & Senegal \\
\hline Netherlands & Bulgaria & Peru & Djibouti & Sierra Leone \\
\hline New Zealand & Chile & Philippines & Dominica & Solomon Islands \\
\hline Norway & China & Poland & Eritrea & South Sudan \\
\hline Portugal & Colombia & Qatar & Ethiopia & St. Lucia \\
\hline San Marino & Costa Rica & Romania & Gambia, The & St. Vincent and the Grenadines \\
\hline Spain & Croatia & Russian Federation & Ghana & Sudan \\
\hline Sweden & Czech Republic* & Saudi Arabia & Grenada & Tajikistan \\
\hline Switzerland & Dominican Republic & Serbia & Guinea & Tanzania \\
\hline United Kingdom & Ecuador & Seychelles & Guinea-Bissau & Timor Leste \\
\hline \multirow[t]{20}{*}{ United States } & Egypt & Singapore * & Guyana & Togo \\
\hline & El Salvador & Slovak Republic * & Haiti & Tonga \\
\hline & Equatorial Guinea & Slovenia * & Honduras & Tuvalu \\
\hline & Estonia * & South Africa & Kenya & Uganda \\
\hline & Fiji & Sri Lanka & Kiribati & Uzbekistan \\
\hline & Gabon & St. Kitts and Nevis & Kyrgyz Republic & Vanuatu \\
\hline & Georgia & Suriname & Laos & Vietnam \\
\hline & Guatemala & Swaziland & Lesotho & Yemen \\
\hline & Hong Kong SAR * & Syria & Liberia & Zambia \\
\hline & Hungary & Taiwan POC * & Madagascar & Zimbabwe \\
\hline & India & Thailand & Malawi & \\
\hline & Indonesia & Trinidad \& Tobago & & \\
\hline & Iran, I. Rep. Of & Tunisia & & \\
\hline & Iraq & Turkey & & \\
\hline & Israel * & Turkmenistan & & \\
\hline & Jamaica & U.A.E. & & \\
\hline & Jordan & Ukraine & & \\
\hline & Kazakhstan & Uruguay & & \\
\hline & Korea * & Venezuela & & \\
\hline & Kosovo & & & \\
\hline
\end{tabular}

Note: 1 / * represent the newly industrialized economies (NIEs). They are currently classified as AMs by the WEO, however, we classify them as EMs in this study because their growth patterns share similarities with EMs and they continue to face similar challenges as EMs.

2/ AMs classification is based on the OECD's member list; LICs classification is based on the IMF PRGT-eligible country list plus Zimbabwe; the rest of countries are classified as EMs. 
Table 2. Country Coverage in Cluster Analysis

\begin{tabular}{llllll}
\hline 1 & Argentina & 10 & Indonesia & 19 & Singapore \\
2 & Brazil & 11 & Israel & 20 & South Africa \\
3 & Chile & 12 & Malaysia & 21 & Korea \\
4 & China & 13 & Mexico & 22 & Thailand \\
5 & Colombia & 14 & Pakistan & 23 & Turkey \\
6 & Egypt & 15 & Peru & 24 & Uruguay \\
7 & Hong Kong SAR & 16 & Philippines & 25 & Venezuela \\
8 & Hungary & 17 & Poland & & \\
9 & India & 18 & Saudi Arabia & & \\
\hline
\end{tabular}

Table 3. Country Coverage in Taxonomy Analysis

\begin{tabular}{rlllll}
\hline 1 & Algeria & 19 & Hong Kong SAR & 37 & Philippines \\
2 & Angola & 20 & Hungary & 38 & Poland \\
3 & Argentina & 21 & India & 39 & Romania \\
4 & Armenia & 22 & Indonesia & 40 & Russian Federation \\
5 & Azerbaijan & 23 & Iraq & 41 & Singapore \\
6 & Bosnia and Herzegovina & 24 & Israel & 42 & Slovak Republic \\
7 & Brazil & 25 & Jamaica & 43 & Slovenia \\
8 & Bulgaria & 26 & Jordan & 44 & South Africa \\
9 & Chile & 27 & Kazakhstan & 45 & Swaziland \\
10 & China & 28 & Korea & 46 & Taiwan POC \\
11 & Colombia & 29 & Latvia & 47 & Thailand \\
12 & Costa Rica & 30 & Lithuania & 48 & Tunisia \\
13 & Croatia & 31 & Malaysia & 49 & Turkey \\
14 & Czech Republic & 32 & Mexico & 50 & Ukraine \\
15 & Dominican Republic & 33 & Morocco & 51 & Uruguay \\
16 & Egypt & 34 & Pakistan & 52 & Venezuela \\
17 & Estonia & 35 & Panama & & \\
18 & Guatemala & 36 & Peru & & \\
\hline
\end{tabular}


Table 4. Data Source of Taxonomy Indicators

\begin{tabular}{|c|c|c|c|}
\hline Indicator Name & Description & Data Source & Period \\
\hline \multicolumn{4}{|l|}{ Domestic Angle } \\
\hline Capital Contribution/GDP Growth & Capital contribution to GDP growth divided by GDP growth & Total Economy Database & $2000-2012^{*}$ \\
\hline Labor Contribution/GDP Growth & Labor contribution to GDP growth divided by GDP growth & Total Economy Database & $2000-2012$ \\
\hline TFP Contribution/GDP Growth & TFP contribution to GDP growth divided by GDP growth & Total Economy Database & $2000-2012$ \\
\hline Consumption Contribution/GDP Growth & $\begin{array}{l}\text { Consumption contribution to GDP growth divided by GDP } \\
\text { growth }\end{array}$ & WEO Database & $2000-2013$ \\
\hline Investment Contribution/GDP Growth & Investment contribution to GDP growth divided by GDP growth & WEO Database & $2000-2013$ \\
\hline Net Exports Contribution/GDP Growth & $\begin{array}{l}\text { Export contribution to GDP growth minus import contribution to } \\
\text { GDP growth, divided by GDP growth }\end{array}$ & WEO Database & $2000-2013$ \\
\hline \multicolumn{4}{|l|}{ External Angle } \\
\hline Financial Openness & $\begin{array}{l}\text { External assets plus liabilities, in percent of GDP, excluding } \\
\text { reserve assets }\end{array}$ & $\begin{array}{l}\text { External Wealth of Nations } \\
\text { Database, WEO Database }\end{array}$ & $2000-2010$ \\
\hline Trade Openness & Exports plus imports (goods and services), in percent of GDP & WEO Database & $2000-2012$ \\
\hline Growth of Terms of Trade & Annual growth of terms of trade, in percent change & WEO Database & $2000-2012$ \\
\hline Net Commodity Exporters & Net commodity exports, in percent of GDP & WEO Database & $2000-2010$ \\
\hline Export Share to the Euro Area & $\begin{array}{l}\text { Exports to the Euro Area, in percent of total exports of goods } \\
\text { and services to the world }\end{array}$ & $\begin{array}{l}\text { Direction of Trade Statistics } \\
\text { Database }\end{array}$ & $2000-2012$ \\
\hline Export Share to the United States & $\begin{array}{l}\text { Exports to the United States, in percent of total exports of goods } \\
\text { and services to the world }\end{array}$ & $\begin{array}{l}\text { Direction of Trade Statistics } \\
\text { Database }\end{array}$ & $2000-2012$ \\
\hline Export Share to China & $\begin{array}{l}\text { Exports to China, in percent of total exports of goods and } \\
\text { services the world }\end{array}$ & $\begin{array}{l}\text { Direction of Trade Statistics } \\
\text { Database }\end{array}$ & $2000-2012$ \\
\hline
\end{tabular}

* There are more than 50 percent missing data in 2013 so we exclude the 2013 data. 


\section{REFERENCE}

Agénor, PR., O. Canuto, and M. Jelenic, 2012. "Avoiding Middle-Income Growth Traps," World Bank - Economic Premise, issue 98 (November), pp. 1-7. (Washington: World Bank).

Blanchard, O.J. and P.A. Diamond, 1989, "The Beveridge Curve," Brookings Papers on Economic Activity, Vol. 1, pp. 1-60.

Cubeddu, L., A. Culiuc, G. Fayad, Y. Gao, K. Kochhar, A. Kyobe, C. Oner, R. Perrelli, S. Sanya, E. Tsounta, and Z. Zhang, 2014, "Emerging Markets in Transition: Growth Prospects and Challenges," Staff Discussion Note 14/6 (Washington: International Monetary Fund).

Fayad, G. and R. Perrelli, 2014, "Growth Surprises and Synchronized Slowdowns in Emerging Markets-An Empirical Investigation,” IMF Working paper WP/14/173 (Washington: International Monetary Fund).

Gourinchas Pierre-Olivier. and Rey, Helene, 2013, "External Adjustment, Global Imbalances, and Valuation Effects," NBER Working Paper No. 19240.

International Monetary Fund, 2014, "World Economic Outlook—Recovery Strengthens, Remains Uneven," (Washington, April 2014).

Mishra, P., K. Moriyama, P. N'Diaye, and L. Nguyen, 2014, “Impact of Fed Tapering Announcements on Emerging Markets Affected?" IMF Working paper WP/14/109 (Washington: International Monetary Fund).

Lane, P.R. and G.M. Milesi-Ferretti, 2007, "The External Wealth of Nations Mark II: Revised and Extended Estimates of Foreign Assets and Liabilities, 1970-2004," Journal of International Economics 73(November), pp. 223-250.

Lequiller, F. and D. Blades, 2006, "Understanding National Accounts,” (Paris: OECD).

Lipton, D., 2013, "Emerging Markets in Transition," Presented at the IMF/World Bank Annual Meetings Conference on October 8, 2013.

Rey, Helene, 2013, "Dilemma not Trilemma: The Global Financial Cycle and Monetary Policy Independence," Jackson Hole Conference Proceedings, Kansas City Fed..

Rostow, W. W., 1959, “The Stages of Economic Growth," The Economic History Review, Volume 12, Issue 1, pages 1-16.

Sala-I-Martin, Xavier X., 1997, "I Just Ran Two Million Regressions," The American Economic Review, Vol. 87, No. 2, Papers and Proceedings of the Hundred and Fourth Annual Meeting of the American Economic Association, pp. 178-183. 
Solow, R., 1956, "A Contribution to the Theory of Economic Growth," The Quarterly Journal of Economics, Vol. 70, No. 1, pp. 65-94.

StataCorp, 2013, "Stata 13 Base Reference Manual—Introduction to cluster-analysis commands," College Station, TX: Stata Press.

The Conference Board, 2014, "Total Economy Database Methodological Notes," (New York: The Conference Board).

Vázqueza, S.T. and A. Sumner, 2013, "Revisiting the Meaning of Development: A Multidimensional Taxonomy of Developing Countries," The Journal of Development Studies, Vol. 49, issue 12, pp. 1728-1745. 